\title{
Volcanic ash layers in Lake El'gygytgyn: eight new regionally significant chronostratigraphic markers for western Beringia
}

\author{
C. van den Bogaard ${ }^{1}$, B. J. L. Jensen ${ }^{2,}{ }^{*}$, N. J. G. Pearce ${ }^{3}$, D. G. Froese $^{2}$, M. V. Portnyagin ${ }^{1}$, V. V. Ponomareva ${ }^{4}$, and \\ V. Wennrich ${ }^{5}$ \\ ${ }^{1}$ GEOMAR Helmholtz-Zentrum für Ozeanforschung Kiel, Wischhofstr. 1-3, 24148 Kiel, Germany \\ ${ }^{2}$ Department of Earth and Atmospheric Sciences, 1-26 Earth Sciences Building, University of Alberta, Edmonton, \\ $\mathrm{AB}, \mathrm{T} 6 \mathrm{G} 2 \mathrm{E} 3$, Canada \\ ${ }^{3}$ Department of Geography \& Earth Sciences, Aberystwyth University, Llandinam Building, Penglais Campus, \\ Aberystwyth, SY23 3DB, Wales, UK \\ ${ }^{4}$ Institute of Volcanology and Seismology, Petropavlovsk-Kamchatsky, Russia \\ ${ }^{5}$ University of Cologne, Institute for Geology and Mineralogy, Cologne, Germany \\ * current address: School of Geography, Archaeology and Palaeoecology, Queen's University Belfast, UK
}

Correspondence to: C. van den Bogaard (cbogaard@geomar.de)

Received: 10 August 2013 - Published in Clim. Past Discuss.: 29 October 2013

Revised: 12 March 2014 - Accepted: 14 March 2014 - Published: 23 May 2014

\begin{abstract}
Ash layers from explosive volcanic eruptions (i.e., tephra) represent isochronous surfaces independent from the environment in which they are deposited and the distance from their source. In comparison to eastern Beringia (nonglaciated Yukon and Alaska), few Plio-Pleistocene distal tephra are known from western Beringia (non-glaciated arctic and subarctic eastern Russia), hindering the dating and correlation of sediments beyond the limit of radiocarbon and luminescence methods. The identification of eight visible tephra layers (T0-T7) in sediment cores extracted from Lake El'gygytgyn, in the Far East Russian Arctic, indicates the feasibility of developing a tephrostratigraphic framework for this region. These tephra range in age from ca $45 \mathrm{ky}$ to $2.2 \mathrm{My}$ old, and each is described and characterized by its major-, minor-, trace-element and $\mathrm{Pb}$ isotope composition. These data show that subduction-zone-related volcanism from the Kurile-Kamchatka-Aleutian Arc and Alaska Peninsula is the most likely source, with $\mathrm{Pb}$ isotope data indicating a Kamchatkan volcanic source for tephra layers T0-T5 and T7, while a source in the Aleutian Arc is possible for tephra T6. The location of Lake El'gygytgyn relative to potential source volcanoes $(>1000 \mathrm{~km}$ ) suggests these tephra are regionally distributed over a large area. These deposits provide a unique opportunity to correlate the highresolution paleoenvironmental records of Lake El'gygytgyn to other terrestrial paleoenvironmental archives from western
\end{abstract}

Beringia and marine records from the western North Pacific and Bering Sea, and to move towards the development of a robust integrated framework between the continuous paleoclimatic records of Lake El'gygytgyn and other terrestrial and marine records in NE Eurasia.

\section{Introduction}

\subsection{Lake drilling program and resultant cores}

Lake El'gygytgyn is located in the Far East Russian Arctic $\left(67^{\circ} 30^{\prime} \mathrm{N}, 172^{\circ} 5^{\prime} \mathrm{E}\right), 100 \mathrm{~km}$ north of the Arctic Circle (Fig. 1). The $12 \mathrm{~km}$ wide and $175 \mathrm{~m}$ deep lake formed within a meteorite impact crater created $3.58 \pm 0.04$ million years ago (Gurov et al., 1978, 2007; Layer, 2000), and was cored under a jointly funded project led by the International Continental Scientific Drilling Program (ICDP) in winter 2008/2009. Two pilot cores (Lz1024, PG1351) were collected from Lake El'gygytgyn during initial pre-site surveys (Juschus et al., 2009), followed by the main drilling program that collected three cores from the center of the lake (ICDP site 5011: holes 5011-1A, 5011-1B, 5011-1C; 67²29.98' N, $172^{\circ} 06.23^{\prime} \mathrm{E}$ ), and one permafrost core at the lake margin (ICDP site 5011-3; 76 $29.1^{\prime} \mathrm{N}, 171^{\circ} 56.7^{\prime} \mathrm{E}$ ) (Melles et al., 2011, 2012). Approximately $318 \mathrm{~m}$ of lacustrine sediment 


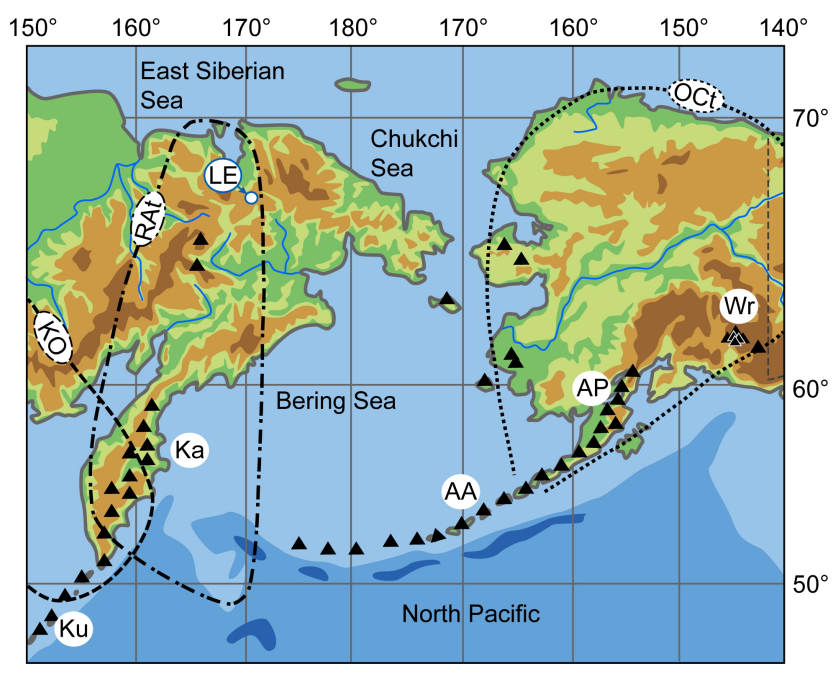

Figure 1. Location of Lake El'gygytgyn (LE) in relation to volcanic areas in the Kuriles (Ku), Kamchatka (Ka), Aleutian Arc (AA) and Alaska Peninsula (AP). Reconstructed distribution patterns of Old Crow tephra (OCt; 124 ka; Preece et al., 2011b), Rauchua tephra (RAt; $\sim 177 \mathrm{ka}$; Ponomareva et al., 2013b) and KO tephra (KO; $7 \mathrm{ka}$; Derkachev et al., 2004) illustrate the potential for widespread tephra distribution in this region. The Wrangell volcanic field (Wr) and other smaller cinder cones and maars, indicated by additional triangular markers, are too far afield and/or do not produce the type of tephra deposits that are found in Lake El'gygytgyn. During glacial times, the Bering shelf between Russia and Alaska was exposed, and only mountainous areas in this region experienced limited glaciation, creating the glacial refugium known as Beringia. As a result, Beringia contains terrestrial paleoenvironmental records that rival marine deposits in their richness and length.

were cored without hiatuses, spanning the Mid Pliocene to present (Melles et al., 2012). Tephra layers were identified and collected from all five lake cores, and were initially correlated by stratigraphy and assigned numerically based names, T0-T7.

\subsection{Background}

Tephra resulting from explosive volcanic eruptions can be distributed over vast areas. Because an eruption occurs over days to weeks, each tephra layer represents an isochronous horizon in the different types of depositional environments, in which it is preserved. Each tephra potentially has a unique geochemical fingerprint, allowing the correlation of the archives they occur in, and some can even be independently dated by physical dating methods (e.g., Shane et al., 1996; Westgate et al., 2001; Giaccio et al., 2012). The value of tephra layers has become increasingly recognized in climate and environmental studies over the last few decades. Tephra have been recovered from soil records, loess deposits, lake sediments, peat bogs, archaeological sites, marine and ice cores. As cryptotephra layers - a volcanic ash layer not visible to the naked eye - they have been traced as far as $7000 \mathrm{~km}$ from their source (e.g., Dugmore, 1989; Grönvold et al., 1995; Pilcher et al., 1996; van den Bogaard and Schmincke, 2002; Wastegård, 2002; Davies et al., 2003, 2012; Dörfler et al., 2012; Jensen et al., 2012; PyneO'Donnell et al., 2012; Lane et al., 2013).

The tephra beds present in Lake El'gygytgyn are of particular interest because of its location within western Beringia (Brigham-Grette et al., 2007). Western Beringia is the Eurasian half of Beringia, a large region extending from eastern Siberia to far northwestern Canada that was never glaciated (e.g., Hultén, 1937; Hopkins, 1967; Schirrmeister et al., 2013). The lack of glaciation and presence of permafrost has resulted in exceptionally well-preserved paleoenvironmental archives that go well beyond the last glacialinterglacial cycle (e.g., Westgate et al., 1990; Sher, 1997; Froese et al., 2009; Minyuk and Ivanov, 2012). In eastern Beringia (Yukon and Alaska), abundant volcanic ash from the Aleutian Arc-Alaska Peninsula and Wrangell volcanic field have been instrumental in providing a means to date and correlate these archives back approximately $2.5 \mathrm{My}$ (e.g., Preece et al., 1999, 2011a, b; Jensen et al., 2008, 2011, 2013; Reyes et al., 2010). However, because few tephra have been recognized in western Beringian sediments, and the idea that prevailing wind directions tend to keep tephra "out of reach" of this region, little work has been done to examine the exposures for their presence. This has had a significant impact on attempting to identify sediments that are beyond the limits of radiocarbon and luminescence dating (e.g., Sher, 1991).

Lake El'gygytgyn sediment cores contain eight visible tephra layers that are up to several centimeters thick. The closest known volcanic field to Lake El'gygytgyn is more than $300 \mathrm{~km}$ away, and volcanoes with known explosive eruptions that have been active during the Late Neogene are $\geq 1000$ kilometers away in the Kurile-Kamchatka-Aleutian Arc and Alaska Peninsula (Fig. 1). This implies that this lake holds a record of distant very large magnitude eruptions, which must be distributed widely over western Beringia. In fact, initial analyses of the "T1 tephra" from the pilot core Lz1024 indicate that it correlates to the Rauchua tephra that is thought to be Kamchatka-sourced and present at coastal bluffs on the East Siberian Sea as well as in the Bering Sea (SO201-2-81KL) and western North Pacific (SO201-240KL) marine cores (Ponomareva et al., 2013b). The correlation of T1, a tephra only $1 \mathrm{~cm}$ thick in the Lake El'gygytgyn cores, to the Rauchua tephra, suggests that each individual layer (several $>1 \mathrm{~cm}$ thick) has the potential to play an important role in correlating and dating the disparate paleoenvironmental records of this region.

With this study our goal is to provide a detailed geochemical fingerprint for each individual visible tephra layer in the Lake El'gygytgyn cores. These data support the stratigraphic correlations that have been made between the five lake cores, and enable us to identify the most likely source regions. The geochemical fingerprints - comprising major, minorand trace-element geochemistry and lead $(\mathrm{Pb})$ isotopes - 
will allow for the future identification of these tephra beds in other depositional settings, where they have been preserved, providing important new chronostratigraphic markers for western Beringia. These tephra will also facilitate independent correlation of the Lake El'gygytgyn climate records, particularly to the marine records from the Bering Sea and western North Pacific thus providing a means to compare age models, and allow inter-regional comparisons with sufficiently high temporal precision to discuss climatic synchronicity.

\section{Summary of analytical methods}

All visible tephra layers identified in the cores were sampled and investigated petrologically prior to analysis by electron probe microanalysis (EPMA) and laser ablation inductively coupled plasma-mass spectrometry (LA-ICP-MS) for compositional fingerprinting, whereby the major-, minor-, trace-element and $\mathrm{Pb}$ isotopic composition of single volcanic glass shards was determined (all data provided in the Supplements). Major and minor-element geochemistry was determined using wavelength dispersive EPMA at the University of Alberta, Edmonton (e.g., Jensen et al., 2008, 2011), and at GEOMAR, Kiel (e.g., Ponomareva et al., 2013b). Both laboratories contributed to the recent INTAV (International Quaternary Association's focus group on tephrochronology) comparison of tephrochronology laboratories, which confirmed the high quality of the major-element data produced by both instruments (Kuehn et al., 2011). Additionally, both laboratories run the Lipari obsidian standard as a secondary glass standard to track the quality of calibration and performance through each run (Kuehn et al., 2011). Therefore, both instruments produce data sets that are identical within statistical deviations, and the secondary standard data allow direct comparison of the data sets and help correct for potential issues arising from interlaboratory calibration differences.

Trace-element analyses were performed by LA-ICP-MS at Aberystwyth University, UK, on the glass component of individual shards using ablation craters with diameters in the range of 10-20 $\mu \mathrm{m}$. Most analyses were carried out on the same sample mounts used for the majority of the EPMA. Detailed methods are described in Pearce et al. (2011); NIST 612 was used for calibration (Pearce et al., 1997), and ${ }^{29} \mathrm{Si}$ as the internal standard, using concentrations determined by EPMA. After rejection of analyses for the incorporation of phenocrysts and/or microlites (e.g., using elevated $\mathrm{Ca}$ or $\mathrm{Sr}$ for the presence of feldspar) into the ablated material (see analytical protocols established in Pearce et al., 2002, 2004a, 2007), a total of 226 individual shards were analyzed from the eight tephra units in Lake El'gygytgyn. Analysis of the MPI-DING ATHO-G reference rhyolitic glass (GeoReM; Jochum et al., 2006) shows that accuracy is good.

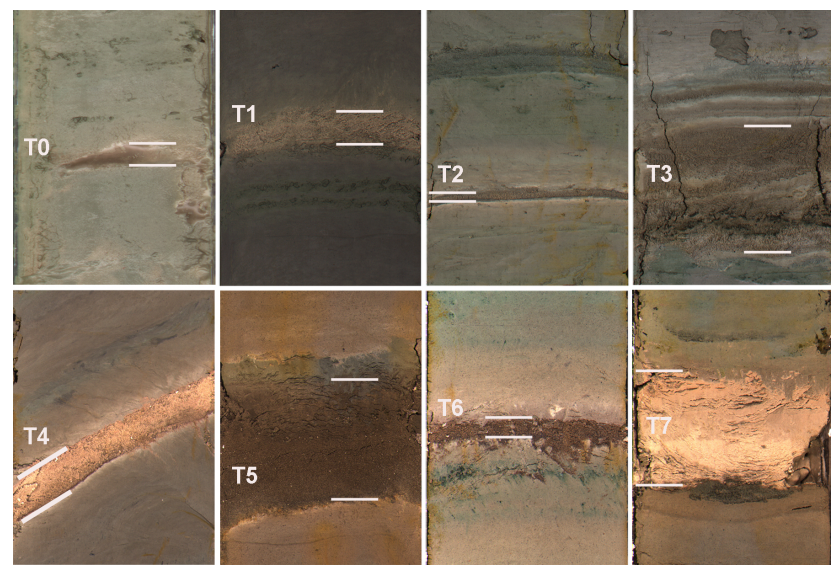

Figure 2. Photos of core sections with detected tephra layers from Lake El'gygtgyn: T0 (core Lz1024-5 I), T1 (core 5011-1B-1H2), T2 (core 5011-1B-7H2), T3 (core 5011-1B-10H2), T4 (core 50111A-19H1), T5 (core 5011-1A-19H2), T6 (core 5011-1A-25H1), T7 (core 5011-1A-35E1). Length of each segment is $12 \mathrm{~cm}$.

$\mathrm{Pb}$ isotope analyses were also performed by LA-ICP-MS at Aberystwyth University on a total of 190 individual glass shards from all tephra deposits. Methods used were those described by Westgate et al. (2011a). Analyses were performed using 20 or $30 \mu \mathrm{m}$ ablation craters, and calibrated against the $\mathrm{Pb}$ isotope ratio of the NIST 612 glass, with analytical accuracy monitored by analysis of US Geological Survey (USGS) glass reference materials. At such relatively small crater diameters, precision and accuracy are reduced compared to analysis of larger samples (e.g., by solution ICP-MS or large spot sizes using LA-ICP-MS), but this provides reconnaissance data suitable for preliminary interpretations (Westgate et al., 2011a). Full details of all analytical methods and results are given in Appendix A and the Supplement.

\section{The El'gygytgyn tephra record}

Eight tephra layers were recognized in the main cores (T0T7), with two present in the pilot cores (T0-T1) (Table 1). The layers are several millimeters up to $6.9 \mathrm{~cm}$ thick. In most layers, the top few millimeters of the layers appeared reworked. The ash horizons are composed of $99 \%$ volcanic material as seen in smear slides.

All layers form distinct tephra horizons separated from each other by several centimeters to decimeters of sediment (Fig. 2). Thicknesses were measured in the opened core. Individual tephra in the cores are assigned working names and numbered from top to bottom (tephra T0-T7). Tephra layers have a white to dark brown appearance, and comprise shards that are mainly colorless or pale yellow to brown. Particle morphologies include highly vesicular pumice, tubular and blocky pumice, bubble-wall shards and non-vesicular platy shards; igneous crystals are rare in the tephra layers (Fig. 3). 
Table 1. Positions and ages of tephra layers identified in Lake El'gygytgyn sediments. Core abbreviations are as follows: 1 - PG1351; 2 Lz1024; A - 5011-1A; B - 5011-1B; and C - 5011-1C. Core positions in Lake El'gygytgyn as in Melles et al. (2011). Age estimates and composite depth from Nowaczyk et al. (2013).

\begin{tabular}{|c|c|c|c|c|c|c|c|c|c|c|}
\hline Tephra & Core & Lab ID Kiel & $\begin{array}{l}\text { Lab ID } \\
\text { Alberta }\end{array}$ & $\begin{array}{l}\text { Depth in } 1, \\
2(\mathrm{~m})\end{array}$ & $\begin{array}{l}\text { Depth in } \\
\text { A (m) }\end{array}$ & $\begin{array}{l}\text { Depth in } \\
\mathrm{B}(\mathrm{m})\end{array}$ & $\begin{array}{l}\text { Composite } \\
\text { core } \\
\text { depth }(\mathrm{m})\end{array}$ & $\begin{array}{l}\text { Thickness } \\
(\mathrm{cm})\end{array}$ & $\begin{array}{l}\text { Age } \\
\text { estimate } \\
(\mathrm{ka})\end{array}$ & Description \\
\hline T0 & 1,2 & T0-4 core 1 & $\begin{array}{l}\text { UA1936, } \\
\text { UA1937, } \\
\text { UA1938 }\end{array}$ & $\begin{array}{l}2.00-2.01 \text { in } 1, \\
2.45-2.46 \text { in } 2\end{array}$ & & & $\begin{array}{l}2.54- \\
2.55\end{array}$ & 1 & $\begin{array}{l}>45 \\
\text { (Anderson, } \\
\text { Lozhkin, } \\
\text { 2002) }\end{array}$ & Whitish fine ash \\
\hline $\mathrm{T} 1$ & $1,2, \mathrm{~A}, \mathrm{~B}$ & $\begin{array}{l}\text { T1-2 core } 2 \\
\text { T1-3/ ET1-3 } \\
\text { core B }\end{array}$ & $\begin{array}{l}\text { UA1939, } \\
\text { UA1940, } \\
\text { UA1941 }\end{array}$ & $\begin{array}{l}7.83-7.84 \text { in } 1, \\
7.91-7.92 \text { in } 2\end{array}$ & $\begin{array}{l}5.085- \\
5.095\end{array}$ & $\begin{array}{l}5.148- \\
5.158\end{array}$ & $\begin{array}{l}7.88- \\
7.89\end{array}$ & 1 & 177 & Yellowish fine ash \\
\hline $\mathrm{T} 2$ & $\mathrm{~A}, \mathrm{~B}$ & $\begin{array}{l}\text { T2-1 core } A \\
\text { T2- } 2 \text { core } B\end{array}$ & $\begin{array}{l}\text { UA1942, } \\
\text { UA1943 }\end{array}$ & & $\begin{array}{l}24.415- \\
24.420\end{array}$ & $\begin{array}{l}24.293- \\
24.298\end{array}$ & $\begin{array}{l}27.52- \\
27.52\end{array}$ & 0.5 & 674 & Greyish fine ash \\
\hline $\mathrm{T} 3$ & A, B & $\begin{array}{l}\text { T3- } 1 \text { core } B \\
\text { T3- } 2 \text { core } B \\
\text { T3-3 core B }\end{array}$ & $\begin{array}{l}\text { UA1944, } \\
\text { UA1945, } \\
\text { UA1946, } \\
\text { UA1947 }\end{array}$ & & $\begin{array}{l}33.090- \\
33.159\end{array}$ & $\begin{array}{l}32.971- \\
33.027\end{array}$ & $\begin{array}{l}36.41- \\
36.47\end{array}$ & 6,9 & 918 & $\begin{array}{l}\text { Fine ash at the } \\
\text { bottom and top, } \\
\text { coarser ash in the } \\
\text { middle }\end{array}$ \\
\hline $\mathrm{T} 4$ & $\mathrm{~A}, \mathrm{~B}$ & $\begin{array}{l}\text { T4- } 1 \text { core A } \\
\text { T4-4 core B }\end{array}$ & $\begin{array}{l}\text { UA1948, } \\
\text { UA1949, } \\
\text { UA1950, } \\
\text { UA1951 }\end{array}$ & & $\begin{array}{l}56.565- \\
56.576\end{array}$ & $\begin{array}{l}56.945- \\
56.960\end{array}$ & $\begin{array}{l}60.79- \\
60.80\end{array}$ & 1.1 & 1411 & $\begin{array}{l}\text { Fine white ash, } \\
\text { folded layer }\end{array}$ \\
\hline $\mathrm{T} 5$ & $\mathrm{~A}, \mathrm{~B}$ & $\begin{array}{l}\text { T5- } 1 \text { core A } \\
\text { T5-3 core B }\end{array}$ & $\begin{array}{l}\text { UA1952, } \\
\text { UA1953, } \\
\text { UA1954 }\end{array}$ & & $\begin{array}{l}58.519- \\
58.559\end{array}$ & $\begin{array}{l}58.433- \\
58.475\end{array}$ & $\begin{array}{l}62.04- \\
62.08\end{array}$ & 4 & 1434 & $\begin{array}{l}\text { Dark brown fine } \\
\text { ash layer }\end{array}$ \\
\hline T6 & A, B & $\begin{array}{l}\text { T6- } 1 \text { core A } \\
\text { T6- } 2 \text { core B }\end{array}$ & $\begin{array}{l}\text { UA1955, } \\
\text { UA1956 }\end{array}$ & & $\begin{array}{l}75.092- \\
75.099\end{array}$ & $\begin{array}{l}75.167- \\
75.176\end{array}$ & $\begin{array}{l}79.25- \\
79.26\end{array}$ & $0.7-0.9$ & 1775 & $\begin{array}{l}\text { White, medium to } \\
\text { fine ash }\end{array}$ \\
\hline $\mathrm{T} 7$ & $\mathrm{~A}, \mathrm{~B}, \mathrm{C}$ & $\begin{array}{l}\text { T7- } 1 \text { core } B \\
\text { T7- } 2 \text { core } B\end{array}$ & $\begin{array}{l}\text { UA2014, } \\
\text { UA2015 }\end{array}$ & & $\begin{array}{l}100.981- \\
101.015\end{array}$ & $\begin{array}{l}100.715- \\
101.7855\end{array}$ & $\begin{array}{l}104.93- \\
105.00\end{array}$ & 7 & 2225 & $\begin{array}{l}\text { White-grey fine ash } \\
\text { layer }\end{array}$ \\
\hline
\end{tabular}

Shards are up to $400 \mu \mathrm{m}$ in diameter (T7), but the median diameter is $40 \mu \mathrm{m}$. All of the tephra layers have distinct individual visual and chemical characteristics. Glass shards were analyzed from all horizons. More than 900 electron micro probe analyses on individual glass shards from the eight tephra layers have been obtained from both laboratories. The eight tephra layers have glass shards that are chiefly rhyolite to dacite $\left(\mathrm{SiO}_{2}>65 \mathrm{wt} . \%\right)$; one tephra (T5) has glass shards ranging from rhyolite to basaltic andesite $\left(\mathrm{SiO}_{2} 76-54 \mathrm{wt} . \%\right)$ in composition (Fig. 4). The tephra layers are medium- to high-K subalkaline composition (Figs. 4, 5). All of them show high $\mathrm{Cl}$ contents $>0.1 \mathrm{wt} . \%$ (Fig. 5). Major-oxide composition of shards from individual tephra layers are homogenous except T3 and T5, which vary systematically (Figs. 4 and 5). The tephra layers resemble each other compositionally, but can be distinguished by their major-element composition, such as $\mathrm{SiO}_{2}$ and $\mathrm{K}_{2} \mathrm{O}$ concentrations (Fig. 5), traceelement composition (Fig. 6), glass shard morphologies, relative stratigraphic position, and age (Table 1).

Twenty-six trace elements were determined from each of the 8 sampled El'gygytgyn tephra layers by LA-ICP-MS (see Pearce et al., 2002, 2004a, b, 2007). There are many similarities between each of the tephras in their general traceelement contents. Except for T5, all samples show a distinct anomaly at $\mathrm{Sr}$ and Eu (Fig. 6, Table 3a) indicating fractiona- tion of plagioclase. Using a series of bivariate plots of compatible (in silicic magmas) and incompatible elements, it is possible to readily distinguish among most of the tephras (Fig. 6). Particularly characteristic are the elements Rb, Ba, $\mathrm{Zr}$, Y, and the HREE (heavy rare earth elements), which can be combined (e.g., to $\mathrm{Ba} / \mathrm{Y}, \mathrm{Ba} / \mathrm{Ho}, \mathrm{Zr} / \mathrm{Ba}, \mathrm{Ba} / \mathrm{Th}$ ) to better show compositional groupings. Tephras T1, T5, and T7 have distinctive trace-element compositions readily separated using $\mathrm{Rb}, \mathrm{Ba}, \mathrm{Y}$ and $\mathrm{Zr}$. Tephras $\mathrm{T} 0$ and $\mathrm{T} 6$ can be separated using $\mathrm{Nb}$ and $\mathrm{Y}$, and whilst $\mathrm{T} 2, \mathrm{~T} 3$ and $\mathrm{T} 4$ have very similar trace-element compositions, they can be distinguished by differences in their Ba/Y ratio (Fig. 6). Each of the tephra horizons represents a distinct eruption event or tephra marker, and are described from youngest to the oldest.

\subsection{Tephra 0}

The youngest tephra visible in the cores was found in the pilot core Lz1024-5 I as a $1 \mathrm{~cm}$ thick very fine whitish ash layer (Fig. 2), as well as cores Lz1029-8 and Lz1039-2 at $1.59-1.61 \mathrm{~m}$ and $2.12-2.13 \mathrm{~m}$ below lake floor, respectively (Juschus et al., 2007). The tephra consists of platy, highly vesicular, colorless glass shards, up to $160 \mu \mathrm{m}$, except in the pilot core, where the shards are finer-grained $(<80 \mu \mathrm{m})$ (Fig. 3). The glass is chemically homogeneous with $73 \mathrm{wt} . \%$ 
Table 2. Major-element geochemistry of Lake El'gygytgyn tephra from both the University of Alberta (UA) and Kiel laboratories given as averages. Both = data from UA and Kiel combined. Analyses of single glass shards are provided in the Supplement Tables S1 and S3. MAX and MIN values for tephra T3 and T5 show the range in composition.

\begin{tabular}{|c|c|c|c|c|c|c|c|c|c|c|c|c|c|}
\hline Lab & Tephra & & $\mathrm{SiO}_{2}$ & $\mathrm{TiO}_{2}$ & $\mathrm{Al}_{2} \mathrm{O}_{3}$ & $\mathrm{FeO}$ & $\mathrm{MnO}$ & $\mathrm{MgO}$ & $\mathrm{CaO}$ & $\mathrm{Na}_{2} \mathrm{O}$ & $\mathrm{K}_{2} \mathrm{O}$ & $\mathrm{P}_{2} \mathrm{O}_{5}$ & $\mathrm{~F}$ \\
\hline UA & T0 & MEAN & 72,89 & 0,50 & 14,01 & 2,88 & 0,13 & 0,57 & 2,45 & 4,65 & 1,77 & & \\
\hline & & SD & 0,52 & 0,06 & 0,26 & 0,13 & 0,04 & 0,06 & 0,13 & 0,15 & 0,07 & & \\
\hline & & $n$ & 70 & 70 & 70 & 70 & 70 & 70 & 70 & 70 & 70 & & \\
\hline Kiel & T0 & MEAN & 72,64 & 0,50 & 13,94 & 2,86 & 0,13 & 0,54 & 2,36 & 4,97 & 1,79 & 0,08 & 0,03 \\
\hline & & SD & 0,72 & 0,04 & 0,34 & 0,14 & 0,04 & 0,08 & 0,21 & 0,09 & 0,07 & 0,02 & 0,03 \\
\hline & & $n$ & 19 & 19 & 19 & 19 & 19 & 19 & 19 & 19 & 19 & 19 & 19 \\
\hline Both & T0 & MEAN & 72,84 & $0, \mathbf{5 0}$ & 14,00 & 2,88 & 0,13 & 0,57 & 2,43 & 4,72 & 1,78 & 0,08 & 0,03 \\
\hline & & SD & 0,57 & 0,05 & 0,27 & 0,13 & 0,04 & 0,06 & 0,16 & 0,19 & 0,07 & 0,02 & 0,03 \\
\hline & & $n$ & 89 & 89 & 89 & 89 & 89 & 89 & 89 & 89 & 89 & 19 & 19 \\
\hline UA & $\mathrm{T} 1$ & MEAN & 77,77 & 0,24 & 12,38 & 1,22 & 0,06 & 0,22 & 1,20 & 3,96 & 2,80 & & \\
\hline & & SD & 0,39 & 0,06 & 0,22 & 0,13 & 0,03 & 0,03 & 0,08 & 0,15 & 0,11 & & \\
\hline & & $n$ & 73 & 73 & 73 & 73 & 73 & 73 & 73 & 73 & 73 & & \\
\hline Kiel & $\mathrm{T} 1$ & MEAN & 77,57 & 0,22 & 12,37 & 1,16 & 0,06 & 0,20 & 1,19 & 4,21 & 2,79 & 0,02 & 0,03 \\
\hline & & $\mathrm{SD}$ & 0,17 & 0,02 & 0,10 & 0,10 & 0,04 & 0,02 & 0,03 & 0,12 & 0,08 & 0,02 & 0,04 \\
\hline & & $n$ & 71 & 71 & 71 & 71 & 71 & 71 & 71 & 71 & 71 & 71 & 71 \\
\hline Both & T1 & MEAN & 77,67 & 0,23 & 12,37 & 1,19 & 0,06 & 0,21 & 1,20 & 4,08 & 2,80 & 0,02 & 0,03 \\
\hline & & & $\mathbf{0 , 3 2}$ & 0,05 & 0,18 & $\mathbf{0 , 1 2}$ & $\mathbf{0 , 0 3}$ & 0,03 & 0,06 & 0,19 & $\mathbf{0 , 1 0}$ & 0,02 & 0,04 \\
\hline & & $n$ & 144 & 144 & 144 & 144 & 144 & 144 & 144 & 144 & 144 & 71 & 71 \\
\hline UA & $\mathrm{T} 2$ & MEAN & 74,14 & 0,41 & 13,63 & 2,52 & 0,10 & 0,40 & 1,81 & 4,25 & 2,58 & & \\
\hline & & $\mathrm{SD}$ & 1,20 & 0,09 & 0,38 & 0,36 & 0,04 & 0,11 & 0,35 & 0,20 & 0,15 & & \\
\hline & & $n$ & 52 & 52 & 52 & 52 & 52 & 52 & 52 & 52 & 52 & & \\
\hline Kiel & $\mathrm{T} 2$ & MEAN & 73,21 & 0,42 & 13,78 & 2,61 & 0,10 & 0,42 & 1,88 & 4,76 & 2,53 & 0,06 & 0,06 \\
\hline & & & 0,95 & 0,07 & 0,27 & 0,32 & 0,04 & 0,09 & 0,26 & 0,17 & 0,11 & 02 & 0,05 \\
\hline & & $n$ & 49 & 49 & 49 & 49 & 49 & 49 & 49 & 49 & 49 & 49 & 49 \\
\hline Both & T2 & MEAN & 73,69 & 0,41 & 13,70 & 2,56 & 0,10 & 0,41 & 1,84 & 4,50 & 2,56 & 0,06 & 0,06 \\
\hline & & SD & 1,17 & 0,08 & 0,34 & $\mathbf{0 , 3 5}$ & 0,04 & $\mathbf{0 , 1 0}$ & 0,31 & $\mathbf{0 , 3 1}$ & 0,13 & 0,02 & 0,05 \\
\hline & & $n$ & 101 & 101 & 101 & 101 & 101 & 101 & 101 & 101 & 101 & 49 & 49 \\
\hline UA & $\mathrm{T} 3$ & MEAN & 69,71 & 0,75 & 14,57 & 3,99 & 0,15 & 0,94 & 3,07 & 4,62 & 2,05 & & \\
\hline & & SD & 1,56 & 0,09 & 0,34 & 0,59 & 0,03 & 0,23 & 0,49 & 0,27 & 0,19 & & \\
\hline & & $n$ & 70 & 70 & 70 & 70 & 70 & 70 & 70 & 70 & 70 & & \\
\hline & & MAX & 74,05 & 1,12 & 15,61 & 6,07 & 0,24 & 1,82 & 4,76 & 5,34 & 2,56 & & \\
\hline & & MIN & 64,48 & 0,63 & 13,65 & 2,69 & 0,07 & 0,59 & 1,97 & 3,59 & 1,49 & & \\
\hline Kiel & $\mathrm{T} 3$ & MEAN & 69,25 & 0,73 & 14,63 & 3,93 & 0,14 & 0,88 & 2,94 & 5,05 & 2,08 & 0,15 & 0,05 \\
\hline & & $\mathrm{SD}$ & 1,33 & 0,07 & 0,47 & 0,50 & 0,05 & 0,22 & 0,47 & 0,23 & 0,16 & 0,05 & 0,04 \\
\hline & & $n$ & 81 & 81 & 81 & 81 & 81 & 81 & 81 & 81 & 81 & 81 & 81 \\
\hline & & MAX & 73,31 & 0,97 & 16,88 & 5,16 & 0,27 & 1,51 & 4,16 & 5,57 & 2,78 & 0,33 & 0,15 \\
\hline & & MIN & 65,18 & 0,56 & 13,51 & 2,46 & 0,03 & 0,37 & 1,85 & 3,97 & 1,76 & 0,06 & 0,00 \\
\hline Both & T3 & MEAN & 69,47 & 0,74 & 14,61 & 3,96 & 0,15 & 0,91 & 3,00 & 4,85 & 2,07 & 0,15 & 0,05 \\
\hline & & SD & 1,46 & 0,08 & 0,41 & $\mathbf{0 , 5 4}$ & $\mathbf{0 , 0 4}$ & 0,23 & 0,48 & $\mathbf{0 , 3 3}$ & 0,17 & 0,05 & 0,04 \\
\hline & & $n$ & 151 & 151 & 151 & 151 & 151 & 151 & 151 & 151 & 151 & 81 & 81 \\
\hline & & MAX & 74,05 & 1,12 & 15,61 & 6,07 & 0,24 & 1,82 & 4,76 & 5,34 & 2,56 & & \\
\hline & & MIN & 64,48 & 0,63 & 13,65 & 2,69 & 0,07 & 0,59 & 1,97 & 3,59 & 1,49 & & \\
\hline UA & $\mathrm{T} 4$ & MEAN & 71,33 & 0,68 & 14,23 & 3,42 & 0,16 & 0,64 & 2,20 & 4,90 & 2,31 & & \\
\hline & & SD & 0,33 & 0,06 & 0,11 & 0,11 & 0,04 & 0,04 & 0,10 & 0,27 & 0,06 & & \\
\hline & & $n$ & 118 & 118 & 118 & 118 & 118 & 118 & 118 & 118 & 118 & & \\
\hline Kiel & $\mathrm{T} 4$ & MEAN & 70,52 & 0,69 & 14,34 & 3,43 & 0,16 & 0,66 & 2,19 & 34 & 2,34 & 0,12 & 0,05 \\
\hline & & SD & 0,23 & 0,02 & 0,12 & 0,20 & 0,04 & 0,03 & 0,06 & 0,12 & 0,04 & 0,02 & 0,05 \\
\hline & & $n$ & 42 & 42 & 42 & 42 & 42 & 42 & 42 & 42 & 42 & 42 & 42 \\
\hline Both & T4 & MEAN & 71,00 & 0,68 & 14,29 & 3,43 & 0,16 & 0,65 & 2,21 & 5,05 & 2,32 & 0,12 & 0,05 \\
\hline & & SD & $\mathbf{0 , 4 8}$ & 0,05 & $\mathbf{0 , 1 2}$ & 0,15 & 0,04 & $\mathbf{0 , 0 3}$ & 0,08 & 0,35 & 0,06 & 0,02 & 0,05 \\
\hline & & $n$ & 160 & 160 & 160 & 160 & 160 & 160 & 160 & 160 & 160 & 42 & 42 \\
\hline UA & T5 & MEA & 62,06 & 1, & $1:$ & 7 & 0 & 2, & 5 & 4,20 & 1,57 & & \\
\hline & & SD & 5,90 & 0,26 & 0,88 & 2,45 & 0,05 & 1,14 & 2,19 & 0,46 & 0,64 & & \\
\hline & & $n$ & 67 & 67 & 67 & 67 & 67 & 67 & 67 & 67 & 67 & & \\
\hline & & MA & 75,75 & 1,44 & 16,70 & 11,16 & 0,28 & 4, & 8,84 & 5,21 & 3,60 & & \\
\hline & & MIN & 53,95 & 0,30 & 13,13 & 1,55 & 0,07 & 0,23 & 1,03 & 3,18 & 0,89 & & \\
\hline Kiel & T5 & MEA & 59,03 & 1, & 15, & 8 & 0 & 2, & 6 , & 4 & 34 & 5 & 03 \\
\hline & & SD & 4,06 & 0,20 & 1,00 & 1,90 & 0,06 & 0,89 & 1,63 & 0,43 & 0,44 & 0,12 & 0,04 \\
\hline & & $n$ & 45 & 45 & 45 & 45 & 45 & . & 45 & 45 & 45 & 45 & 45 \\
\hline & & MA) & 70,33 & 1,43 & 19,71 & 11,14 & 0,36 & 4,05 & 9,67 & 5,36 & 2,50 & 0,57 & 0,15 \\
\hline & & MIN & 53,76 & 0,54 & 12,91 & 3,54 & 0,07 & 0,54 & 2,21 & 3,51 & 0,68 & 0,10 & 0,00 \\
\hline Both & T5 & MEAN & 60,84 & 1,19 & 15,71 & 8,27 & 0,20 & 2,87 & 6,36 & 4,41 & 1,34 & 0,35 & 0,03 \\
\hline & & SD & 5,43 & 0,20 & . & & & & 1,63 & & & 0,12 & 0,04 \\
\hline & & $n$ & 112 & 1 & 11 & 112 & 112 & & & & 112 & 45 & 45 \\
\hline & & MA & 75,75 & 1,44 & 19,71 & 11,16 & 0,36 & 4, & 9, & 5,36 & 3,60 & & \\
\hline & & MIN & 53,76 & 0,30 & 12,91 & 1,55 & 0,07 & 0,23 & 1,03 & 3,18 & 0,68 & & \\
\hline UA & T6 & MEAN & 70,94 & 0,65 & 13,9 & 4 & 0 & 0,64 & 2,58 & 4,48 & 2,43 & & \\
\hline & & & 0,29 & 0,05 & 0,10 & 0,12 & 0,03 & 0,04 & 0,12 & 0,31 & 0,07 & & \\
\hline & & $n$ & 50 & 50 & 50 & 50 & 50 & 50 & 50 & 50 & 50 & & \\
\hline Kiel & T6 & $\mathrm{ME}$ & 70,26 & 0 , & 1. & 4,07 & 0 & 0 & 2, & t & 2,46 & 0,11 & 0,04 \\
\hline & & & 0,28 & 0,03 & 0,16 & 0,19 & 0,04 & 0,03 & 0,09 & 0,17 & 0,05 & 0,02 & 0,04 \\
\hline & & $n$ & 40 & 40 & 40 & 40 & 40 & 40 & 40 & 40 & 40 & 40 & 40 \\
\hline Both & T6 & MEAN & 70,64 & 0,66 & 13,96 & 4,07 & 0,13 & 0,64 & 2,59 & 4,65 & 2,45 & 0,11 & 0,04 \\
\hline & & SI & 0,45 & 0,04 & 0,1 & $\mathbf{0 , 1 5}$ & $\mathbf{0 , 0 3}$ & 0,04 & 0,11 & $\mathbf{0 , 3 2}$ & 0,06 & 0,02 & 0,04 \\
\hline & & $n$ & 90 & 90 & 90 & 90 & 90 & 90 & 90 & 90 & 90 & 40 & 40 \\
\hline UA & $\mathrm{T} 7$ & MEA & 77, & 0 & 12 & 0,71 & 0,09 & 0,11 & 0,63 & 3,81 & 4,25 & & \\
\hline & & SI & 0,27 & 0,03 & 0,10 & 0,04 & 0,03 & 0,02 & 0,03 & 0,31 & 0,22 & & \\
\hline & & $n$ & 48 & 48 & 48 & 48 & 48 & 48 & 48 & 48 & 48 & & \\
\hline Kiel & $\mathrm{T} 7$ & MEAN & 77,67 & 0,12 & 12,96 & 0,66 & 0,08 & 0,09 & 0,62 & 3,58 & 4,02 & 12 & 03 \\
\hline & & $\mathrm{S}$ & 0,19 & 0,02 & 0,09 & 0,0 & 0,04 & 0,02 & 0,02 & 0,11 & 0,14 & 0,01 & 0,03 \\
\hline & & $n$ & 52 & 52 & 52 & 52 & 52 & 52 & 52 & 52 & 52 & 52 & 52 \\
\hline Both & T7 & $\mathrm{M}$ & 77, & $\mathbf{0}$, & 12, & 0,66 & 0,08 & 0,09 & 0,62 & 3 , & 4, & 2 &, 03 \\
\hline & & SI & $\mathbf{0 , 3 0}$ & 0,0 & 0,09 & 0,08 & $\mathbf{0 , 0 4}$ & 0,02 & 0,02 & 0,11 & $\mathbf{0 , 1 4}$ & 0,01 & 0,03 \\
\hline & & . & 100 & 100 & 100 & 100 & 100 & 100 & 100 & 100 & 100 & 52 & 52 \\
\hline
\end{tabular}



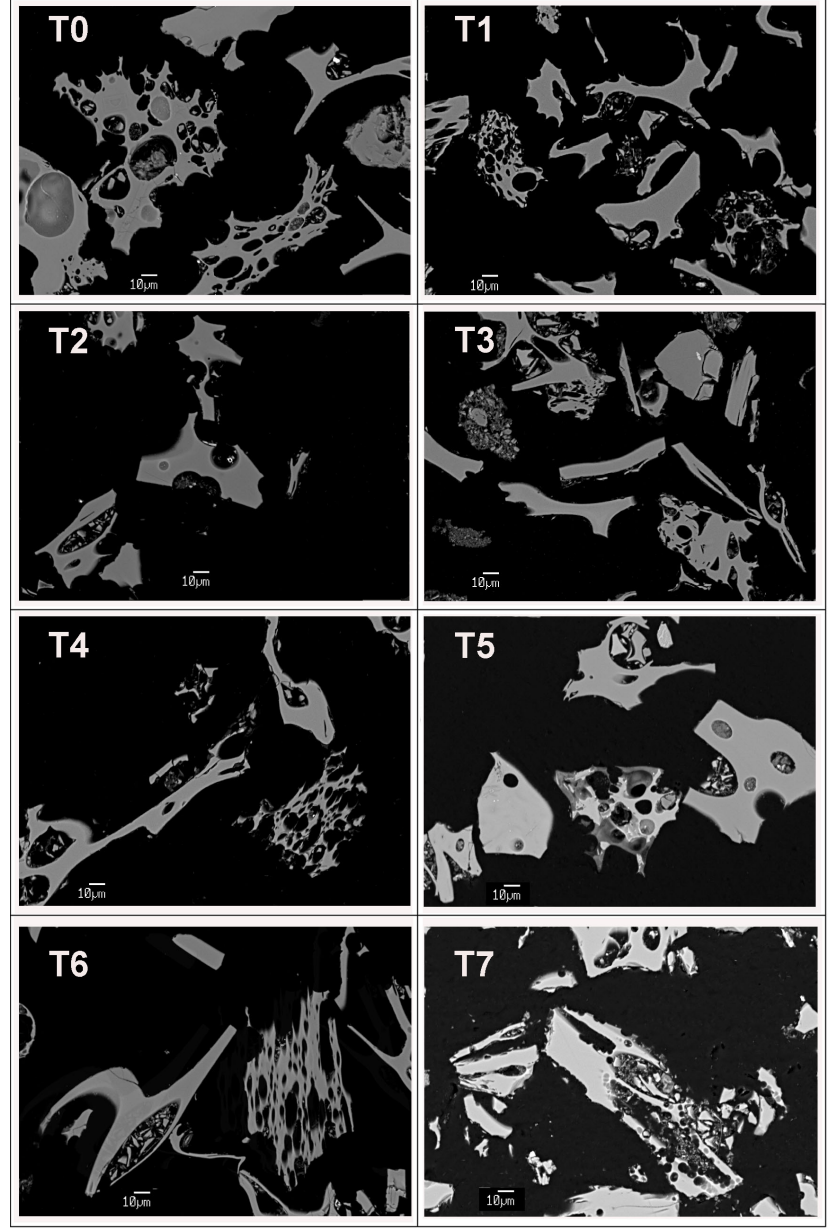

Figure 3. Backscatter electron images of characteristic glass shards from tephra layers T0-T7 from Lake El'gygytgyn. Scale bar is $10 \mu \mathrm{m}$.

$\mathrm{SiO}_{2}$ (Fig. 5, Table 2), and with distinct $\mathrm{Y}$ and $\mathrm{Nb}$ values (Fig. 6d).

\subsection{Tephra 1}

T1 comprises tephra beds in the pilot core Lz1024-9 and in cores $5011-1 \mathrm{~B}-1 \mathrm{H}-2$ and $5011-1 \mathrm{~A}-1 \mathrm{H}-3$. The tephra is present as an approximately $1 \mathrm{~cm}$ thick discrete ash layer of extremely fine to very fine grain size (Fig. 2). It consists mainly of colorless pumiceous shards with a median size of about $40 \mu \mathrm{m}$, and some larger $(<100 \mu \mathrm{m})$, colorless, highly vesicular shards (Fig. 3). The composition of T1 is homogenous. With high $\mathrm{SiO}_{2}$ content of $78 \mathrm{wt} . \%$ it is the most silicic tephra (comparable to T7) of the eight layers (Figs. 4, 5; Table 2), and it has characteristic Y, Rb and Ba contents (Fig. 6).

\subsection{Tephra 2}

T2 occurs in cores $5011-1 \mathrm{~A}-8 \mathrm{H}-1$ and $5011-1 \mathrm{~B}-7 \mathrm{H}-3$ as a $0.5 \mathrm{~cm}$ fine greyish ash (Fig. 2). Glass shards are $\leq 100 \mu \mathrm{m}$

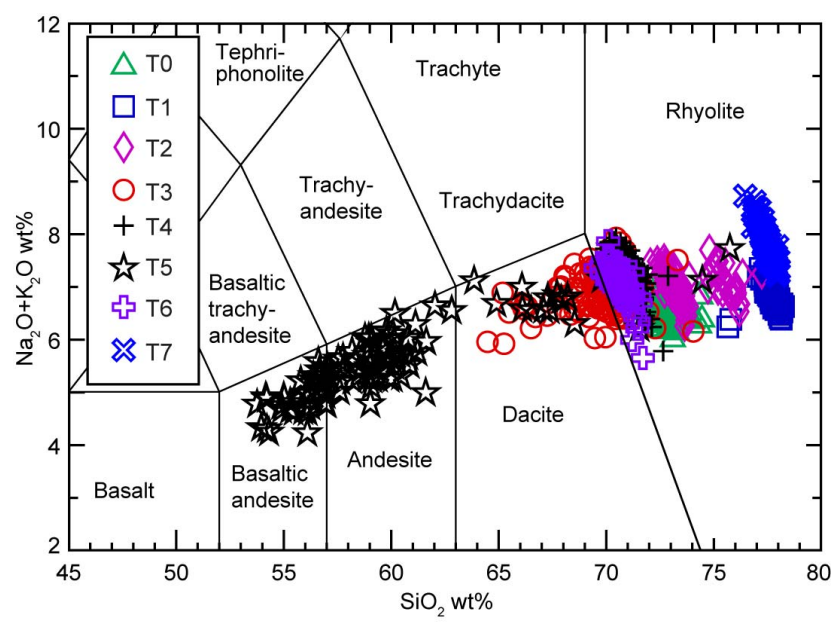

Figure 4. TAS (total alkali silica) classification diagram with fields according to Le Bas et al. (1986). All data are single shard glass analyses normalized to $100 \%$. Data include both sets analyzed in Edmonton and Kiel.

in diameter, colorless, and platy with round vesicles (Fig. 3). The glass composition is bimodal, comprising rhyolitic to rhyodacitic compositions (77 to 72 wt. $\% \mathrm{SiO}_{2}$; Figs. 4 and 5, Table 2).

\subsection{Tephra 3}

T3 occurs in cores 5011-1B-10H-2 and 5011-1A-11H-1, and is a $6 \mathrm{~cm}$ thick graded ash (Fig. 2). The layer is finer grained at the bottom and top, and coarser in the middle, where shards are up to $150 \mu \mathrm{m}$ in diameter. It consists of colorless, vesicular shards, with rare brown glass. The shards have variable $\mathrm{SiO}_{2}$ contents from 74.0 to $64.5 \mathrm{wt}$ \% (Fig. 4). This, and the variation in $\mathrm{MgO}$ concentration from 0.4 to $1.8 \mathrm{wt} . \%$ and of $\mathrm{FeO}$ from 2.5 to $6.1 \mathrm{wt} \%$, suggests an eruption from a chemically zoned magma chamber (Figs. 4, 5; Table 2).

\subsection{Tephra 4}

This prominent, white, $\sim 1 \mathrm{~cm}$ thick tephra layer (Fig. 2) occurs in sections of cores 5011-1B-18H-2 and 5011-1A-19H$1 / 18 \mathrm{H}-3$, which are interpreted as representing a sequence of multiple turbidites, subsequently folded by a larger mass movement (Melles et al., 2012; Sauerbrey et al., 2013). T4 is reworked within these deposits and appears up to three times in the core. This tephra layer consists of colorless tubular pumice and pumiceous and vesicular glass shards (Fig. 3). The median grain size is about $60 \mu \mathrm{m}$; the largest shards are up to $250 \mu \mathrm{m}$. T4 is chemically homogeneous, with a rhyolitic composition of $71 \mathrm{wt} . \% \mathrm{SiO}_{2}$ (Fig. 4, Table 2). 


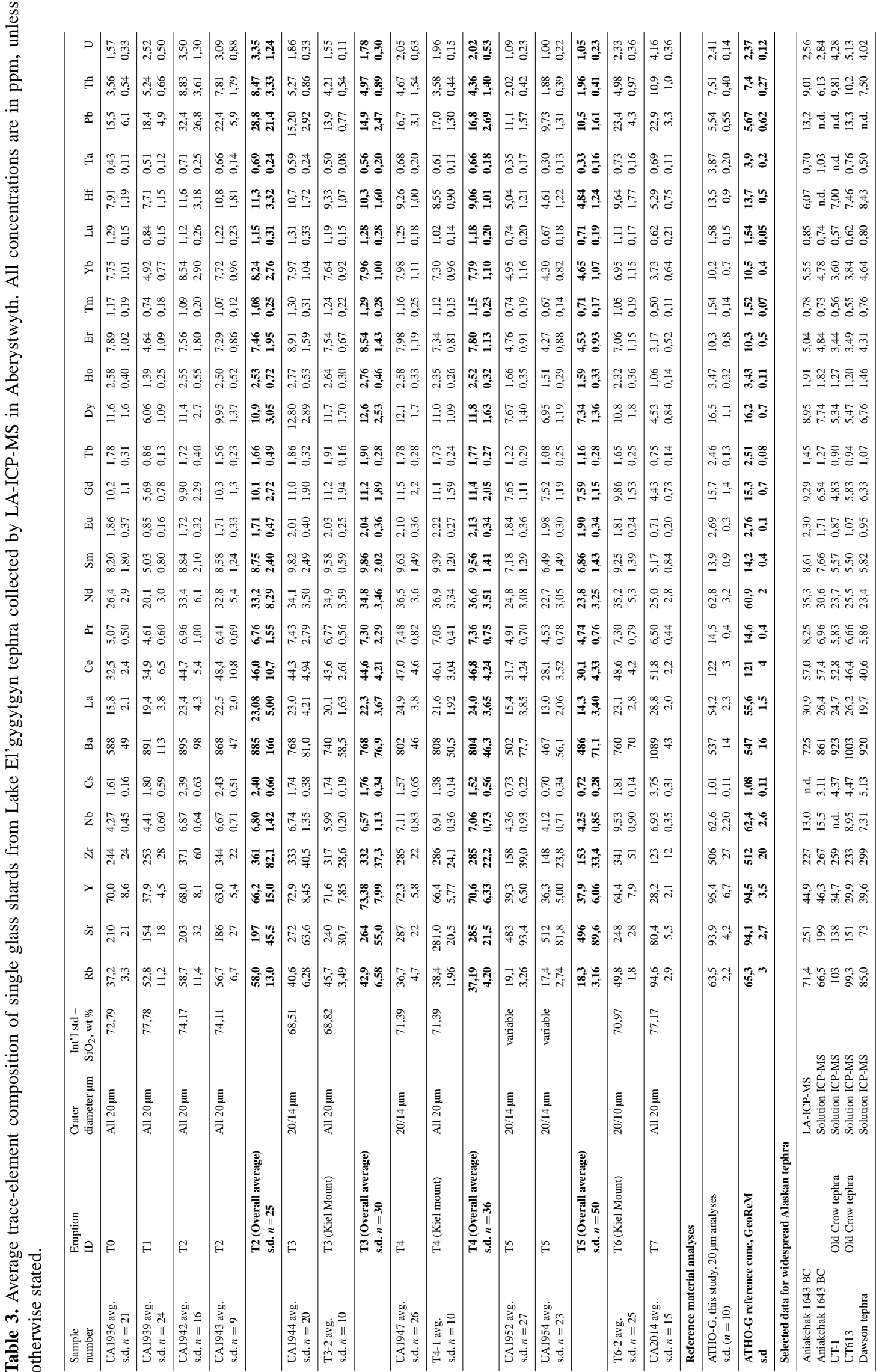


Table 4. Average $\mathrm{Pb}$ isotopic values collected on single glass shards from Lake El'gygytgyn tephra. Avg. = average; $\mathrm{SD}=$ standard deviation; n.r. $=$ not reported RSD $\%$ = relative standard deviation given as percentage $(+$ std dev/mean $\times 1000)$.

\begin{tabular}{|c|c|c|c|c|c|c|c|c|c|c|c|c|}
\hline Samples & $\begin{array}{r}208 \mathrm{~Pb} \\
\text { avg. cps }\end{array}$ & $\begin{array}{r}\text { Avg. Pb } \\
\text { ppm }\end{array}$ & $\begin{array}{r}206 / \\
204 \text { avg }\end{array}$ & $\begin{array}{r}207 / \\
204 \text { avg. }\end{array}$ & $\begin{array}{r}208 / \\
204 \text { avg. }\end{array}$ & $\begin{array}{r}206 / \\
208 \text { avg. }\end{array}$ & $\begin{array}{r}207 / \\
208 \text { avg. }\end{array}$ & $\begin{array}{r}206 / \\
204 \mathrm{SD}\end{array}$ & $\begin{array}{r}207 / \\
204 \text { SD }\end{array}$ & $\begin{array}{r}208 / \\
204 \text { SD }\end{array}$ & $\begin{array}{r}206 / \\
208 \text { SD }\end{array}$ & $\begin{array}{r}207 / \\
208 \mathrm{SD}\end{array}$ \\
\hline $\mathrm{T} 0,30 \mu \mathrm{m}$ & 25941 & 15,5 & 19,063 & 16,026 & 39,518 & 0,4826 & 0,4055 & 0,870 & 0,846 & 2,024 & 0,0071 & 0,0071 \\
\hline $\mathrm{RSD} \%, n=19$ & & & & & & & & $4,6 \%$ & $5,3 \%$ & $5,1 \%$ & $1,5 \%$ & $1,8 \%$ \\
\hline $\mathrm{T} 1,20 \mu \mathrm{m}$ & 16757 & 18,4 & 18,750 & 15,760 & 38,683 & 0,4847 & 0,4075 & 1,570 & 1,275 & 3,252 & 0,0065 & 0,0056 \\
\hline $\mathrm{RSD} \%, n=15$ & & & & & & & & $8,4 \%$ & $8,1 \%$ & $8,4 \%$ & $1,3 \%$ & $1,4 \%$ \\
\hline $\mathrm{T} 2,20 \mu \mathrm{m}$ & 19016 & 22,4 & 18,951 & 16,090 & 39,299 & 0,4822 & 0,4093 & 1,495 & 1,303 & 2,905 & 0,0089 & 0,0091 \\
\hline $\mathrm{RSD} \%, n=19$ & & & & & & & & $7,9 \%$ & $8,1 \%$ & $7,4 \%$ & $1,8 \%$ & $2,2 \%$ \\
\hline $\mathrm{T} 3,30 \mu \mathrm{m}$ & 25596 & 21,1 & 18,281 & 15,451 & 37,877 & 0,4825 & 0,4080 & 1,317 & 1,029 & 2,550 & 0,0067 & 0,0052 \\
\hline $\operatorname{RSD} \%, n=20$ & & & & & & & & $7,2 \%$ & $6,7 \%$ & $6,7 \%$ & $1,4 \%$ & $1,3 \%$ \\
\hline $\mathrm{ET} 3,30 \mu \mathrm{m}$ & 44817 & 21,1 & 18,472 & 15,679 & 38,436 & 0,4806 & 0,4079 & 0,617 & 0,554 & 1,260 & 0,0045 & 0,0044 \\
\hline $\mathrm{RSD} \%, n=20$ & & & & & & & & $3,3 \%$ & $3,5 \%$ & $3,3 \%$ & $0,9 \%$ & $1,1 \%$ \\
\hline $\mathrm{T} 4,20 \mu \mathrm{m}$ & 20107 & 15,9 & 18,116 & 15,236 & 37,553 & 0,4824 & 0,4059 & 1,172 & 0,899 & 2,426 & 0,0063 & 0,0058 \\
\hline $\mathrm{RSD} \%, n=17$ & & & & & & & & $6,5 \%$ & $5,9 \%$ & $6,5 \%$ & $1,3 \%$ & $1,4 \%$ \\
\hline $\mathrm{T} 5$, most $30 \mu \mathrm{m}$, some $20 \mu \mathrm{m}$ & 24498 & 8,76 & 19,193 & 16,107 & 39,548 & 0,4853 & 0,4073 & 1,022 & 0,773 & 1,961 & 0,0072 & 0,0026 \\
\hline $\mathrm{RSD} \%, n=15$ & & & & & & & & $5,3 \%$ & $4,8 \%$ & $5,0 \%$ & $1,5 \%$ & $0,6 \%$ \\
\hline $\mathrm{T} 6$, most $20 \mu \mathrm{m}$, some $30 \mu \mathrm{m}$ & 59358 & 23,4 & 19,090 & 15,752 & 38,884 & 0,4909 & 0,4052 & 1,216 & 0,877 & 2,211 & 0,0126 & 0,0056 \\
\hline $\mathrm{RSD} \%, n=19$ & & & & & & & & $6,4 \%$ & $5,6 \%$ & $5,7 \%$ & $2,6 \%$ & $1,4 \%$ \\
\hline $\mathrm{T} 7,20 \mu \mathrm{m}$ & 26639 & 22,9 & 18,133 & 15,286 & 37,376 & 0,4854 & 0,4090 & 0,867 & 0,957 & 2,016 & 0,0116 & 0,0145 \\
\hline $\mathrm{RSD} \%, n=19$ & & & & & & & & $4,8 \%$ & $6,3 \%$ & $5,4 \%$ & $2,4 \%$ & $3,5 \%$ \\
\hline Aniakchak UT2011, $20 \mu \mathrm{m}$ & 18554 & 12,0 & 19,012 & 15,646 & 38,545 & 0,4933 & 0,4060 & 1,368 & 1,106 & 2,770 & 0,0081 & 0,0077 \\
\hline $\mathrm{RSD} \%, n=18$ & & & & & & & & $7,2 \%$ & $7,1 \%$ & $7,2 \%$ & $1,6 \%$ & $1,9 \%$ \\
\hline \multicolumn{13}{|l|}{ Reference material analyses } \\
\hline GeoReM BCR-2G avg. (95 \% CL) & & $\mathbf{1 1} \pm \mathbf{1}$ & 18,819 & 15,692 & 38,699 & 0,4863 & 0,4054 & 0,007 & 0,006 & $\mathbf{0 , 0 2}$ & 0,0005 & 0,0005 \\
\hline BCR-2G this study $30 \mu \mathrm{m}$ & 27293 & & 18,739 & 15,571 & 38,783 & 0,4832 & 0,4015 & 0,830 & 0,707 & 1,771 & 0,0027 & 0,0051 \\
\hline $\operatorname{RSD} \%, n=10$ & & & & & & & & $4,4 \%$ & $4,5 \%$ & $4,6 \%$ & $0,6 \%$ & $1,3 \%$ \\
\hline Accuracy this study/GeoReM & & & $0,42 \%$ & $0,77 \%$ & $-0,22 \%$ & $0,63 \%$ & $0,95 \%$ & & & & & \\
\hline GeoReM TB1-G (avg. $n=2$ ) & & $18.4 \pm 1.6$ & 18,333 & 15,552 & 38,611 & 0,4748 & 0,4028 & 0,001 & 0,001 & 0,004 & n.r. & n.r. \\
\hline TB-1G this study $30 \mu \mathrm{m}$ & 78931 & & 18,374 & 15,640 & 38,681 & 0,4750 & 0,4043 & 0,287 & 0,295 & 0,572 & 0,0034 & 0,0034 \\
\hline $\mathrm{RSD} \%, n=10$ & & & & & & & & $1,6 \%$ & $1,9 \%$ & $1,5 \%$ & $0,7 \%$ & $0,8 \%$ \\
\hline Accuracy this study/GeoReM & & & $-0,23 \%$ & $-0,57 \%$ & $-0,18 \%$ & $-0,05 \%$ & $-0,38 \%$ & & & & & \\
\hline
\end{tabular}

\subsection{Tephra 5}

Tephra 5 occurs in cores 5011-1A-19H-2 and 5011-1B-19H1. This distinctive $4 \mathrm{~cm}$ thick brownish tephra (Fig. 2) is extremely fine-grained with median and maximum shard sizes of 40 and $80 \mu \mathrm{m}$, respectively. It is comprised of brown to greenish platy tricuspate glass shards, and highly vesicular, colorless shards (Fig. 3). The tephra has the broadest compositional range of all the tephra beds, with $\mathrm{SiO}_{2}$ spanning from 76 to 54 wt.\% (Figs. 4, 5). The variation in $\mathrm{MgO}(0.2-$ $4.0 \mathrm{wt} . \%)$ and $\mathrm{FeO}(1.6-11.1 \mathrm{wt} . \%)$ content suggests that this tephra was erupted from a chemically zoned magma chamber. T5 has the flattest REE profile with the least pronounced Eu anomaly (Fig. 6).

\subsection{Tephra 6}

Tephra 6 occurs in cores 5011-1A-25H-1 and 5011-1B-25H2. It is a $7-9 \mathrm{~mm}$ thick (Fig. 2), medium to fine ash with shards up to $300 \mu \mathrm{m}$ that is comprised of colorless glass shards ranging in morphology from stretched and blocky pumice to platy shards (Fig. 3). Blocky pumice have numerous small, round, evenly sized vesicles. Few brown blocky shards were seen, but all displayed the same morphology as the colorless shards. T6 has a homogeneous major-element composition with $\mathrm{SiO}_{2}$ at $70.6 \pm 0.5 \mathrm{wt} . \%$ and relatively high $\mathrm{Na}_{2} \mathrm{O}$ content of $4.7 \pm 0.3 \mathrm{wt}$.\%. It also has the highest $\mathrm{Nb}$ and Ta concentrations of the eight tephras, and shows the highest HREE and a relatively flat REE profile, similar to T2, T3 and T4 (Fig. 5)

\subsection{Tephra 7}

Tephra 7 is present in the three cores $5011-1 \mathrm{~A}-35 \mathrm{H}-1,5011$ $1 \mathrm{~B}-36 \mathrm{H}-1$ and $5011-1 \mathrm{C}-5 \mathrm{~A}-1$. Shards in this $7 \mathrm{~cm}$ thick white to grey tephra horizon (Fig. 2) are up to $500 \mu \mathrm{m}$ in diameter. They are colorless and comprised of stretched and blocky pumice. Blocky shards contain many evenly distributed vesicles that are generally $\sim 1 \mu \mathrm{m}$ in diameter. The glass margins show extensive scalloping along the edges. The composition of $\mathrm{T} 7$ is homogeneous, with high $\mathrm{SiO}_{2}$ content $(77.5 \pm 0.3 \mathrm{wt} . \%)$, and with the highest $\mathrm{K}_{2} \mathrm{O}$ content $(4.0 \pm 0.1 \mathrm{wt} . \%)$ of the El'gygytgyn tephras. $\mathrm{T} 7$ is also distinct in its trace-element composition, with the highest $\mathrm{Ba}$, $\mathrm{Rb}$, Th, and LREE (light rare earth elements), and the lowest $\mathrm{Sr}$ and HREE, giving it the steepest REE patterns (Fig. 6).

\section{Age of tephra layers}

The three parallel sediment cores from Lake El'gygytgyn were spliced into a composite core, and a high-resolution age model was developed using a multi-proxy approach (Nowaczyk et al., 2013). Magnetostratigraphy provides the 

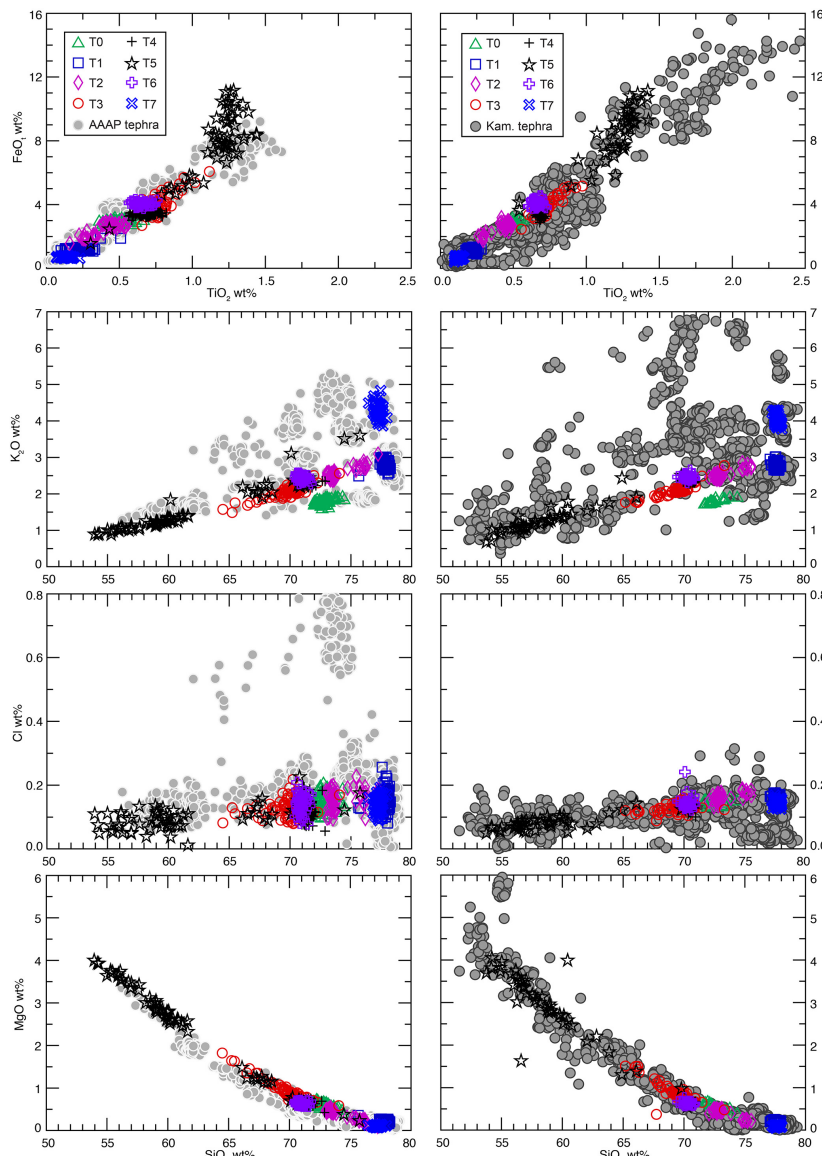

Figure 5. Harker diagrams for major-element geochemistry of T0 T7 in comparison to tephra from Kamchatka and the AAAP (Aleutian Arc-Alaska Peninsula). All data are single shard glass analyses normalized to $100 \%$. Plots on the left compare data collected in Edmonton to a data set of AAAP tephra that have higher similarity coefficients $(>0.90)$ to the tephra examined in this study. Compiled AAAP data were analyzed in Edmonton and are from the internal database, but are limited to tephra that have previously been reported in the literature. Plots on the right compare the majorelement geochemical analyses collected in the Kiel laboratory to Pleistocene Kamchatkan eruptions. Although T0-T7 all plot within the fields designated by the AAAP and Kamchatkan data, they tend to plot more clearly with Kamchatkan data. This is particularly the case for the mafic oxides (e.g., $\mathrm{MgO}$ ).

tie points for the basic age model (Haltia and Nowazcyk, 2013). To further refine the age model, nine additional stratigraphic parameters were synchronously tuned (Nowaczyk et al., 2013). Ages of the tephra beds in this study were determined from the resulting age-depth model (Nowaczyk et al., 2013) (Table 1).

Independent ages for the tephra layers are not yet available. Due to the age and composition of the tephra layers (low to medium $\mathrm{K}$ and datable phenocrysts being absent) direct dating of the tephra layers is difficult. Vesicular glass shards of $63 \mu \mathrm{m}$ and smaller have been dated us- ing a laser Ar-Ar technique; however, analyses carried out on tephra layers from deep sea cores using this approach have been problematic (e.g., Hall and Farrell, 1995). An attempt to date the glass shards of some of the tephra layers from Lake El'gygytgyn using the glass fission-track method is currently being carried out and may in the future provide independent age constraints (J. A. Westgate, personal communication, 2013).

\section{Potential sources of the tephra layers}

\subsection{Continental volcanoes versus island arcs}

Based on major-element geochemical distribution, the tephra layers from Lake El'gygytgyn are characterized by a subalkaline composition (Fig. 4), and likely originate from a subduction-related tectonic setting rather than from intracontinental vents. Even though intracontinental volcanoes in Chukotka are present $\sim 300 \mathrm{~km}$ from Lake El'gygytgyn (Fig. 1), much of their activity was limited to the Cretaceous (Akinin and Miller, 2012); only few centers have been active over the Quaternary (Pevzner et al., 2011). Moreover, these volcanoes are associated with mafic lava fields, dykes and/or cinder cones (Laverov et al., 2006), and are thus unlikely sources for the El'gygytgyn tephras.

Trace-element geochemistry of the Lake El'gygytgyn tephra layers rather suggests that the eruptions originate from subduction-related volcanoes. Magmas formed in nonsubduction-related settings (continental and oceanic hotspots and rifts) are expected to have low ratios of LILE (large ion lithophile elements, e.g., $\mathrm{K}, \mathrm{Rb}, \mathrm{Ba}$ ), Th, $\mathrm{U}$ and LREE (e.g., La, Ce) to HFSE (high-field-strength elements, e.g., Ta, $\mathrm{Nb}, \mathrm{Zr})$ (Gill, 1981; Pearce and Parkinson, 1993). For example, typical characteristics of non-subduction-related rocks are $\mathrm{Th} / \mathrm{Nb}<0.01, \mathrm{La} / \mathrm{Nb}<2$, and $\mathrm{U} / \mathrm{Nb}<0.03$ (Pearce and Parkinson, 1993). The trace-element data for the Lake El'gygytgyn tephras show strong relative enrichment in LILE ( $\mathrm{Rb}, \mathrm{Ba}, \mathrm{Cs})$ in comparison to similar incompatible LREE ( $\mathrm{La}, \mathrm{Ce}$ ) and HFSE (Nb, Ta). Therefore, the majorand trace-element composition of these tephra beds suggests an island arc origin (Figs. 4, 5, 6).

The most likely source for these tephra beds are the many volcanoes that collectively comprise the Kurile-KamchatkaAleutian Arc and Alaska Peninsula, more than $1000 \mathrm{~km}$ away from Lake El'gygytgyn (Fig. 1). Similarly, the Pb isotope data for these tephra beds fall within the compositional envelopes defined by known $\mathrm{Pb}$ isotopic values from Kamchatkan and Alaskan volcanoes (Fig. 7). Collectively, the major, trace and isotope geochemical data suggest that the Kurile-Kamchatka-Aleutian Arc and Alaska Peninsula volcanoes are the most likely sources for the eruptions, and these areas have been active for more than 2 million years (e.g., Siebert and Simkin, 2002; Preece et al., 1999). 


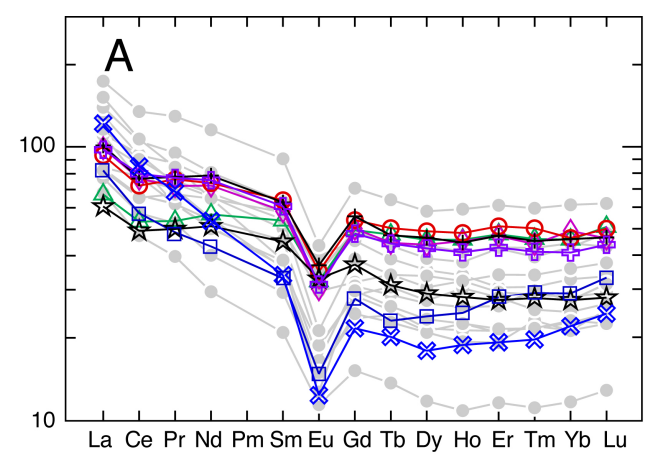

\begin{tabular}{|c|c|c|}
\hline$\triangle \mathrm{TO}$ & ○ T3 & њ 6 \\
\hline$\square \mathrm{T} 1$ & $+\mathrm{T} 4$ & $\approx \mathrm{T} 7$ \\
\hline$\diamond \mathrm{T} 2$ & 之े T5 & - AAAP \\
\hline
\end{tabular}
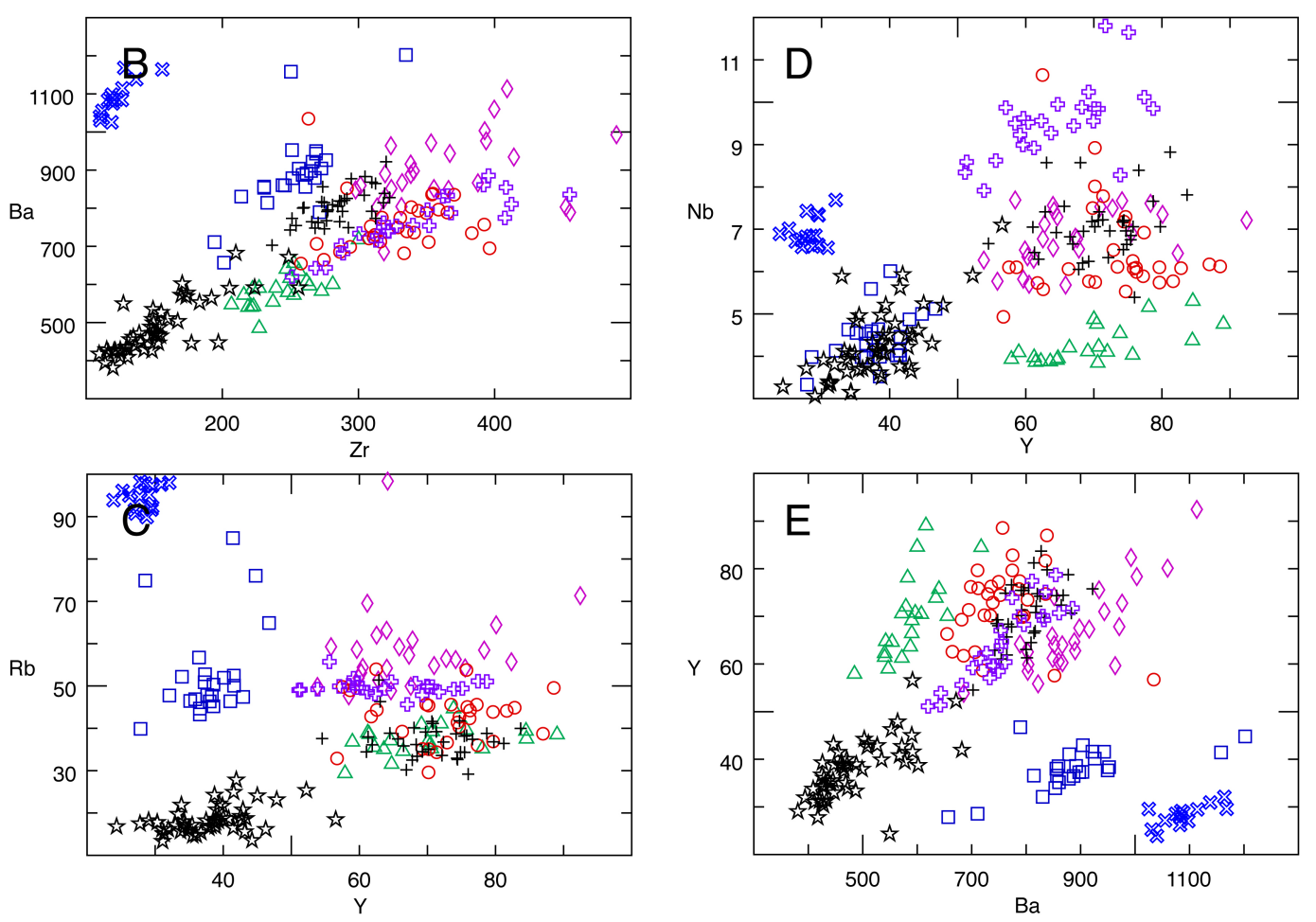

Figure 6. Plots of the trace-element composition of single glass shards for T0-T7. (A) Spider diagram comparing the average REE abundances of each tephra to known AAAP (Aleutian Arc-Alaska Peninsula) Pleistocene tephra (Pearce et al., 2004b; Preece et al., 2011a, b; Jensen et al., unpublished data). Data are normalized to chondrite after Sun and McDonough (1989). (B-E) Plots of trace elements that allow differentiation between each tephra. (B) Zr-Ba, (C), Y-Rb (D), Y-Nb (E) Ba-Y. Tephras T1, T5 and T7 are compositionally distinct, and can be clearly separated based on a combination of $\mathrm{Ba}, \mathrm{Rb}, \mathrm{Zr}$ and $\mathrm{Y}$ (B and $\mathbf{C}$ ). T0 and T6 form separate clusters when compared on their $\mathrm{Y}$ and $\mathrm{Nb}$ concentrations (D). T2, T3 and T4 are more similar, but T3 shows a lower Zr/ Ba ratio than T2 and T4 (B), and these 3 samples all display different $\mathrm{Ba} / \mathrm{Y}$ ratios $(\mathbf{E})$, which can be used to separate them.

\subsection{Island arc: Alaska versus Kamchatka volcanoes}

The predominantly explosive volcanism of the NW Pacific area is related to the subduction of the Pacific Plate under the Eurasian and North America plates, forming the KamchatkaKurile-Aleutian Arc, and the Alaska Peninsula. The majorand trace-element geochemistry of Lake El'gygytgyn tephra falls within the compositional range of both Alaskan and Kamchatkan tephra beds (Figs. 5, 6).

\subsubsection{Alaskan volcanoes}

Alaska is home to over 130 volcanoes, most of which are located in the Aleutian Arc-Alaska Peninsula (AAAP) and the Wrangell volcanic field (e.g., Nye et al., 1998; Fig. 1). Although the Wrangell volcanic field has been active over the last $\sim 25 \mathrm{My}$ (Richter et al., 1990), and the AAAP for $\sim 40$ My (Jicha et al., 2006), most eruptions from these volcanoes are known only by their widespread tephra because most of their proximal deposits became glacially eroded over the past $\sim 3 \mathrm{My}$. 
Much of this distal tephra record is preserved on the terrestrial landscape within widespread loess deposits of eastern Beringia (e.g., Westgate et al., 1990). To date, well over 100 widely distributed distal tephra beds have been identified and characterized from the interior of Alaska and Yukon (e.g., Preece et al., 1999, 2000, 2011a; Jensen et al., 2008, 2013). Although distances from AAAP volcanoes to Lake El'gygytgyn are great, generally between 1600 and $2000 \mathrm{~km}$, tephra with comparable distributions have been documented from these volcanoes in the past (e.g., Jensen et al., 2011; Preece et al., 2011b). This suggests that the AAAP could be a potential source for tephra at the study site. With the Wrangell volcanic field downwind and over $2000 \mathrm{~km}$ from Lake El'gygytgyn, it seems unlikely that visible tephra from these volcanoes would be present in the lake. However, they were not excluded from geochemical comparisons.

Comparison of major- and minor-element geochemistry of Alaskan tephras to the tephras recovered from Lake El'gygytgyn was two-fold. Firstly, all El'gygytgyn tephra were run through the University of Alberta Tephrochronology Lab searchable database to query for potential correlatives. The database uses a similarity coefficient (SC; Borchardt et al., 1972) as the basis for its search. Since some of the tephra beds have large geochemical trends, where averages can be misleading, the standard deviation of $\mathrm{SiO}_{2}$ wt.\% is also used in this search. For tephra beds that may have more than one mode, the average of each population is run through the database independently. Generally, a SC of $>0.95$ demonstrates some similarity between two samples though does not necessarily indicate a correlative bed. Tephra beds with SCs $>0.90$ were further examined visually through Harker diagrams. When the Lake El'gygytgyn tephras were run through the database, no values over 0.93 were obtained for the Alaskan tephras except for T1, which had SCs of 0.94 to 0.96 with the Alyeska Pipeline, Gold Run, P13 and other similar, high $\mathrm{SiO}_{2}$ wt.\% rhyolites (e.g., Westgate et al., 2009; Jensen et al., 2013; Supplement Table S2).

The detailed comparison of major-element geochemistry between the Alaskan and Lake El'gygytgyn tephra suggests there are no obvious correlations. However, to test the database results and explore the overall characteristics of the unknowns in comparison to tephra recovered in Alaska, a series of prominent widely distributed tephra beds - including Aniakchak, Dawson, VT, Old Crow, Gold Run, GI, PAL, HP and PA - were plotted with the El'gygytgyn tephra (e.g., Kaufman et al., 2012; Preece et al., 1999, 2011a, b; Demuro et al., 2008; Westgate et al., 2009; Jensen et al., 2013; Fig. 5). These tephra beds were chosen based on their widespread distribution; they represent the most widely distributed tephra known in Alaska, and some have chemistries broadly similar to the unknowns (e.g., Supplement Table S2). These beds also allow to query the Alaskan tephras to capture variability in terms of age (ca 2 My to $3.6 \mathrm{ky}$ old), and major-element geochemistry (basaltic-andesite to rhyolite). Results indicate that the major-element geochemistry of Lake
El'gygytgyn tephra tend to fall within the compositional range exhibited by this selection of Alaskan tephra (Fig. 5). Some slight systematic differences appear to be present: at less than $\sim 75 \mathrm{SiO}_{2}$ wt.\%, $\mathrm{MgO}, \mathrm{FeO}$ and $\mathrm{CaO}$ tend to be higher at any given $\mathrm{SiO}_{2}$ wt.\% than the Alaskan beds, while $\mathrm{K}_{2} \mathrm{O}$ and $\mathrm{Al}_{2} \mathrm{O}_{3}$ wt.\% tend to be a little lower. In conclusion, while the major-element geochemistry shows some similarities between the Alaskan and Lake El'gygytgyn tephras, it provides no conclusive evidence to support an Alaskan source for the beds. Trace-element geochemistry comparisons between Alaska tephra and T0-T7 are also inconclusive, showing complete overlap (Fig. 6).

The lead isotope data $\left({ }^{206} \mathrm{~Pb},{ }^{207} \mathrm{~Pb}\right.$ and $\left.{ }^{208} \mathrm{~Pb}\right)$ offer the most in terms of delineating (or precluding) a possible Alaskan source. The isotope data are broadly similar for all of the tephra beds except T6, which differs from the other Lake El'gygytgyn tephras by having the highest ${ }^{206} \mathrm{~Pb} /{ }^{208} \mathrm{~Pb}$ and the lowest ${ }^{207} \mathrm{~Pb} /{ }^{208} \mathrm{~Pb}$ ratios. When compared with recent $\mathrm{Pb}$ isotope data compiled from Kamchatka and Alaska volcanics, the majority of samples sit close to or within the envelope of ${ }^{206} \mathrm{~Pb} /{ }^{208} \mathrm{~Pb}$ vs. ${ }^{207} \mathrm{~Pb} /{ }^{208} \mathrm{~Pb}$ for published data for recent Kamchatka volcanic rocks. T6, however, plots firmly within the $\mathrm{Pb}$ isotope field of recent Alaskan volcanic rocks, suggesting a source from further afield may be possible for this bed (Fig. 7). A plot of known and dated Alaska tephra beds in comparison to T0-T7 indicates that frequent eruptions from these volcanoes occurred during deposition of most of the Lake El'gygytgyn tephra (Fig. 8).

\subsubsection{Kamchatka volcanoes}

The Kurile-Kamchatka volcanic arc has a total length of $2000 \mathrm{~km}$, is about $400 \mathrm{~km}$ wide on the Kamchatka Peninsula, and is one of the most active arc segments on earth (Siebert and Simkin, 2002). It has had numerous explosive eruptions, and the largest number of collapse calderas per unit of arc length (Hughes and Mahood, 2008). In the Holocene, more than 37 large volcanic centers and hundreds of monogenetic vents were active in Kamchatka and about 48 volcanoes are known from the Kurile Islands (Gorshkov, 1970; Siebert and Simkin, 2002; Ponomareva et al., 2007). On the Kurile Islands, the eruption history has been reviewed (Ostapenko et al., 1967; Gorshkov, 1970), although the research mainly focused on recent explosive eruptions (e.g., Nakagawa et al., 2002; Belousov et al., 2003; Hasegawa et al., 2012). In Kamchatka, where many explosive eruptions resulted in widespread dispersal of tephra-fall deposits, the Holocene eruptions and their sequences are well known (Braitseva et al., 1987, 1995, 1997, 1998; Kir'yanov et al., 1990; Bazanova and Pevzner, 2001; Gusev et al., 2003; Ponomareva et al., 2004, 2007; Kyle et al., 2011). Many decades of land mapping, correlation of tephra layers, and determination of ages and magnitudes of eruptions have lead to a detailed tephrostratigraphic framework with more than 40 known large explosive eruptions to date. Some Holocene 


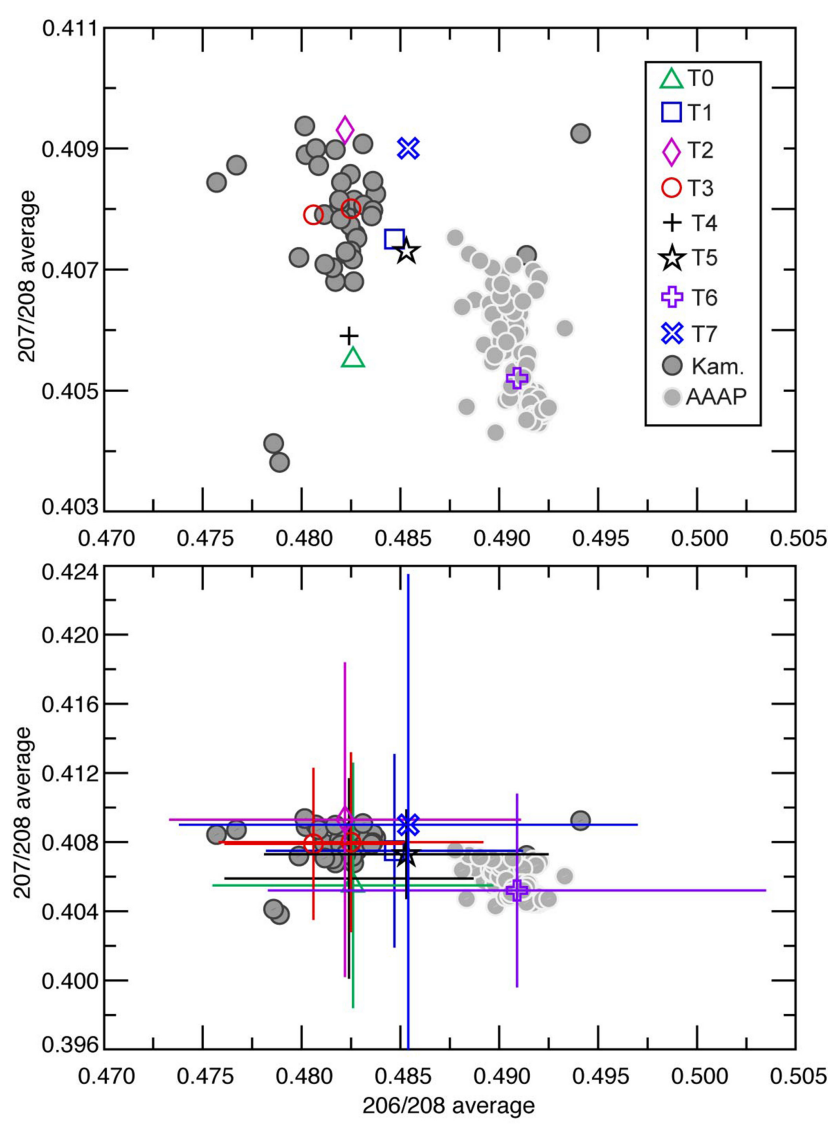

Figure 7. Lead isotope composition of El'gygytgyn tephra layers (T0-T7). Top: average ${ }^{206} \mathrm{~Pb} /{ }^{208} \mathrm{~Pb}$ vs. ${ }^{207} \mathrm{~Pb} /{ }^{208} \mathrm{~Pb}$ for samples from El'gygytgyn core. Bottom: average ${ }^{206} \mathrm{~Pb} /{ }^{208} \mathrm{~Pb}$ vs. ${ }^{207} \mathrm{~Pb} /{ }^{208} \mathrm{~Pb}$ for samples from El'gygytgyn core including $2 \sigma$ error bars. Data are plotted with previously published $\mathrm{Pb}$ isotope compositions of volcanic rocks from the AAAP (Aleutian Arc-Alaska Peninsula) and Kamchatka (Myers and Marsh, 1987; Kepezhinskas et al., 1997; Bindeman et al., 2010; George et al., 2004; Jicha et al., 2004).

Kamchatka tephras have also been identified off Kamchatka in terrestrial and marine environments on the Bering and Karaginsky Islands (Kyle et al., 2011), in the Sea of Okhotsk cores (e.g., Nürnberg and Tiedemann, 2004; Ponomareva et al., 2004; Derkachev et al., 2012), and as far as mainland Asia (Gorbarenko et al., 2002a, b; Ponomareva et al., 2004).

The volcanic history of the early Holocene and the Pleistocene, however, is less well known in Kamchatka and the Kurile Islands. Older Pleistocene tephra have mostly been removed by glaciation and occur only in isolated outcrops. Geological exposure is poor, erosion rates are high, and the vegetation cover is heavy. Only a few widespread ash layers are known from this time. Among these beds, one of the largest explosive eruptions was sourced from Plosky volcano, Kamchatka, at 10.2 ky cal. BP (e.g., Braitseva et al., 1995; Ponomareva et al., 2013a). The K2 tephra at 27354 $30325 \mathrm{cal}$. BP from the northern part of the Kurile Islands most likely originates from Nemo Caldera (Braitsheva et al., 1995; Melekestev et al., 1997; Derkachev et al., 2012). The source of the $177 \mathrm{ka}$ Rauchua tephra is unknown, but it likely comes from the Karymsky volcanic center (Ponomareva et al., 2013b). The Plio-Pleistocene calderas on Kurile Islands and Kamchatka were far larger than the Holocene calderas, and include much thicker proximal pyroclastic deposits (Bindeman et al., 2010), suggesting that the associated tephra layers could be more widely distributed compared to Holocene eruptions. However, the record of these eruptions is poorly known.

The high concentration of tephra layers in marine sediment cores in the adjacent seas supports the notion of a high eruption frequency on Kamchatka in the Plio-Pleistocene. From more than 40 records from the Sea of Okhotsk, spanning the last $350 \mathrm{ky}$, a sequence of about 22 tephra layers has been documented, including at least 9 widespread ash layers (e.g., Gorbarenko et al., 1998, 2000, 2002a, b; Derkachev et al., 2004, 2012; Nürnberg and Tiedemann, 2004). Western North Pacific deep-sea sediments document numerous explosive eruptions over the last 5 million years with an increase in the number and thickness of volcanic ash layers from $2.6 \mathrm{Ma}$ (Cao et al., 1995: ODP Leg 145, sites 881, 882, 883 and 884; Prueher and Rea, 2001: ODP 887, 883, 882). Cores taken on the SO201 Leg 2 cruise of the RV Sonne recovered sediment records spanning the last $180 \mathrm{ky}$ with 14 tephra layers in the Bering Sea and 38 layers in the NW Pacific in Kronotsky Bay and Meiji Seamount (Dullo et al., 2009; Derkachev et al., 2011). High-quality geochemical data on glasses are, however, unavailable for most of the Pleistocene ignimbrites and tephra layers.

Comparison of $\mathrm{Pb}$ isotopes, and major- and minor-element compositions of the known Plio-Pleistocene volcanic eruptions to tephras T0-T7 show an obvious affinity to Kamchatkan tephra (potentially excluding T6). However, with the exception of $\mathrm{T} 1$, there are no obvious correlations to known beds from Kamchatka. To further explore these connections, we look at the activity of the Kamchatka-Kurile arc based on the ages of major caldera-forming eruptions (from Bindemann et al., 2010) relative to the Lake El'gygytgyn beds (Fig. 8). These data suggest that indeed caldera-forming eruptions were taking place at the time of deposition of the Lake El'gygytgyn tephra beds.

The lower $\mathrm{K}_{2} \mathrm{O}$ wt.\% geochemistry of tephra layer T0, with an inferred age of ca $45 \mathrm{ky}$, shows similarities to the composition of tephras and ignimbrites from southern Kamchatka, such as ca 440 ky old Golygin ignimbrites belonging to Pauzhetka Caldera (Bindeman et al., 2010) and to Kuril Lake ignimbrites (Ponomareva et al., 2004). Although T0 glasses have a slightly more mafic composition, their similarity to tephra deposits related to the Kurile Lake caldera, formed $7.6 \mathrm{ka}$, is intriguing. The tephra from this eruption was dispersed over an area of $\leq 3$ million $\mathrm{km}^{2}$, and was found at a distance of $1700 \mathrm{~km}$ from the source (Anderson et al., 1998). During this eruption about $\sim 170 \mathrm{~km}^{3}$ of 


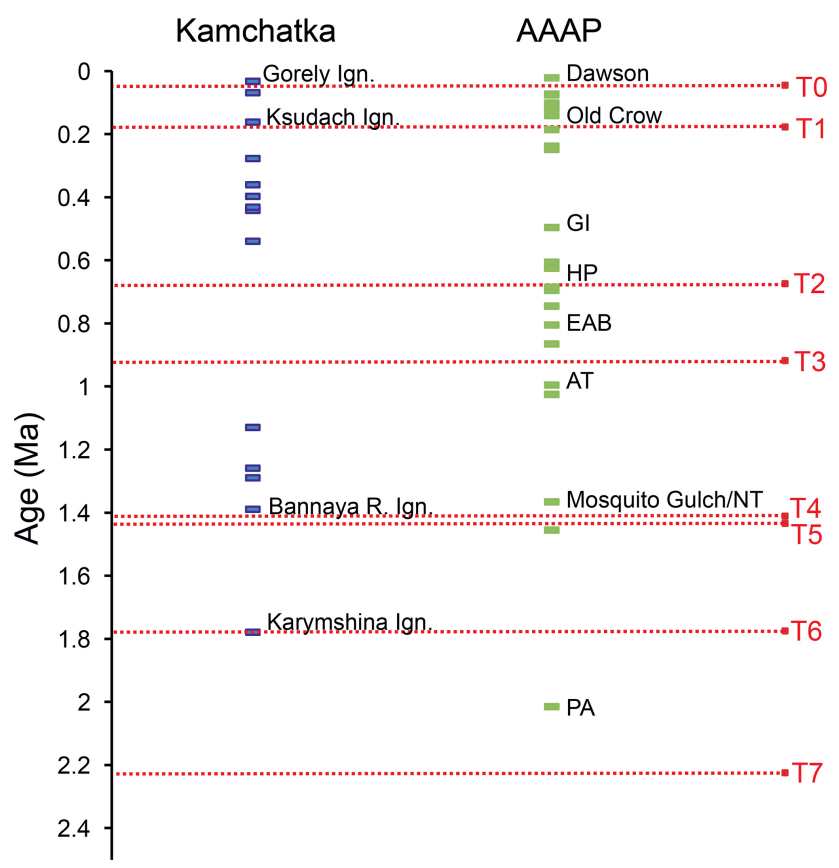

Figure 8. Lake El'gygytgyn tephra ages compared to ages of dated caldera eruptions in Kamchatka and ages of published distal tephra from Aleutian Arc-Alaska Peninsula (AAAP; after Preece et al., 1999; 2011a, b; Westgate et al., 2001, 2011b; Demuro et al., 2008; Bindeman et al., 2010). It is important to note that the frequency of eruptions in Alaska is much greater, but we limited the tephra included in this plot to ones that have been directly dated.

tephra were produced, and the eruption ranks among the largest Holocene explosive eruptions on Earth (Ponomareva et al., 2004). The chemical similarity of the $\mathrm{T} 0$ glasses to this source suggests that this may represent an unknown older eruption from this volcano.

Tephra layer $\mathrm{T} 1$ in core 5011 has been correlated to the second layer in the pilot core Lz1024. The sample from the pilot core is chemically indistinguishable from Rauchua tephra from a terrestrial site in the Far East Russian Arctic, $330 \mathrm{~km} \mathrm{NW}$ of Lake El'gygytgyn (Ponomareva et al., 2013b), and correlates to tephra layers identified in the Bering Sea and Pacific sediment cores SO 201-2-81/85 (Dullo et al., 2009). The distribution of the tephra thicknesses suggests that theses beds likely originate from an eruption in the Karymsky volcanic center in the Kamchatka volcanic arc, although the tephra has not been identified on land (Ponomareva et al., 2013b).

Tephras T2, T3, T4 and T6 have dacitic to rhyolitic (with moderate $\mathrm{K}_{2} \mathrm{O}$ ) compositions, and similar trace-element compositions, which only vary slightly in their ratios of highly incompatible elements (e.g., $\mathrm{Zr} / \mathrm{Nb}, \mathrm{Nb} / \mathrm{Y}$ ); however, these beds clearly separate by differences in their $\mathrm{Ba} / \mathrm{Y}$ ratios. $\mathrm{T} 6$ has a $\mathrm{Pb}$ isotope composition that differs from T2-T4 and may suggest T6 has an Alaskan source. Overall, the compositions are typical for Kamchatka and partic- ularly for centers in the volcanic front around the Karymsky Caldera (Kyle et al., 2011; Ponomareva et al., 2013a). This area has a high density of nested calderas that might be plausible sources for the tephras. Few of the ignimbrite flows related to these calderas have been dated so far, and no exact match in age and composition between published data and these tephra exists at present. One possible candidate could be the dacitic eruption related to Stena-Soboliny Caldera at 1.13 Ma (Bindeman et al., 2010), which could be correlated to the dacitic T3 tephra with an inferred age of ca $0.9 \mathrm{My}$ old, although the age difference of $200 \mathrm{ky}$ makes this correlation questionable. T6 has an identical inferred age of ca $1.78 \mathrm{My}$ old with ignimbrites related to Karymshina Caldera (Bindeman et al., 2010). However, the composition of the ignimbrites produced by this super eruption shows a much more evolved geochemical composition than the glass of T6 (Bindeman et al., 2010).

Dacite-andesitic glasses of tephra T5 imply an andesitic composition for the bulk tephra. Only a few large andesitic eruptions are known in Kamchatka, and all are dated to the Pliocene (3.5-5.7 Ma; Bindeman et al., 2010). These eruptions occurred in the eastern volcanic zone of Kamchatka and in Sredinny Range. None of these eruptions can be directly correlated to T5 tephra, which is dated to $1.4 \mathrm{Ma}$.

The oldest tephra, T7, has a unique composition and a somewhat uncertain age due to possible sediment disturbance in the cores. This makes its correlation to a potential source problematic. Nevertheless, judging from its geochemistry alone, and assuming a source in Kamchatka, it should be located in a small region of the volcanic arc where compositions of tephras are more alkalic, enriched in LILE and depleted in HREE, as exemplified by Opala Volcano in southern Kamchatka (Kyle et al., 2011).

\section{Conclusions}

The eight tephra layers preserved in Lake El'gygytgyn sediments provide a unique opportunity to correlate terrestrial and marine climate archives in the Bering Sea and North Pacific region. They also indicate that there is great potential to find distal ash in western Beringian sediments, which would allow a dated framework for these archives.

Geochemical data indicate that the source of these tephra beds lies in the subduction zone volcanoes that form the Kurile-Kamchatka-Aleutian Arc and Alaska Peninsula. While major-, minor- and trace-element geochemistry is generally inconclusive in determining the potential sources for the beds, the $\mathrm{Pb}$ isotopic data show that the KurileKamchatka arc is the most likely source for seven of the eight tephra. For tephra T6, an Alaskan source is possible, but there is presently no known tephra that correlates to this layer.

The geochemical composition of the seven other tephras suggests a Kamchatka source, and indeed one, T1, has been correlated to the Rauchua tephra, which likely has a 
Kamchatkan source (Ponomareva et al., 2013b). Even though there is evidence for numerous highly explosive eruptions, as seen in nested calderas in the eastern volcanic zone in Kamchatka, the sequence and age of those explosive events are not well constrained. Only a small number of Pleistocene ignimbrites in Kamchatka have been studied with modern analytical tools, and the distal record is limited. Therefore, due to a restricted database available for geochemically fingerprinted Kamchatkan material, none of the remaining Lake El'gygytgyn tephra were successfully correlated, although potential source volcanoes and caldera complexes can be identified. Additionally, tephra layers described from RV Sonne 201, 202, ODP or ICDP cores from the Bering Sea and North Pacific lack sufficient glass geochemistry data needed to compare with Lake El'gygytgyn tephra.

Even though the source volcanoes for tephras T0-T7 are not known at this time, they still offer a unique potential for future correlation of terrestrial and marine sites. The thickness of the Lake El'gygytgyn tephra, over $1500 \mathrm{~km}$ from potential sources, suggest they are widely distributed, and thus, are likely present in numerous depositional settings. The geochemistry presented here will allow for the future identification of these tephra, and their linking to other terrestrial and marine deposits and eventually to their source volcanoes. Ultimately these tephra beds from Lake El'gygytgyn provide the basis for a robust tephrostratigraphic framework for western Beringia that we predict will develop quickly now that the presence of tephra beds in this region is known. The Supplement related to this article is available online
at doi:10.5194/cp-10-1041-2014-supplement.

Acknowledgements. Funding for this research was provided by the International Continental Scientific Drilling Program (ICDP), the US National Science Foundation (NSF), the German Federal Ministry of Education and Research (BMBF), Alfred Wegener Institute (AWI) and GeoForschungsZentrum Potsdam (GFZ), the Russian Academy of Sciences Far East Branch (RAS FEB), the Russian Foundation for Basic Research (RFBR), and the Austrian Federal Ministry of Science and Research (BMWF). The Russian GLAD 800 drilling system was developed and operated by DOSECC Inc., the downhole logging was performed by the ICDP-OSG, and LacCore, at the University of Minnesota, handled core curation.

C. van den Bogaard, M. V. Portnyagin and V. V. Ponomareva received support from the KALMAR Project, a joint GermanRussian project funded by the German Federal Ministry of Education and Research (BMBF). B. J. L. Jensen and D. G. Froese received funding from Natural Sciences and Engineering Research Council of Canada (NSERC). Two reviewers provided constructive comments that improved the manuscript.

The service charges for this open access publication have been covered by a Research Centre of the Helmholtz Association.

Edited by: M. Melles 


\section{Appendix A: Appendix methods}

\section{A1 Petrographic description}

All visible tephra layers in the cores were sampled and described petrographically, prior to chemical analysis for major, trace and $\mathrm{Pb}$ isotope composition by EPMA and LA-ICP-MS.

Tephra layers were identified in the cores directly after opening. Smear slides were taken from every change in lithological composition and checked for volcanic glass shards. All tephra layers were sampled and freeze-dried. Petrologic characteristics of the tephra layers were described from smear slides and polished sections (grain size, mineralogical content). Subsamples for chemical investigations of glass shards were carefully washed in distilled water to sieve off finest grains $(<6 \mu \mathrm{m})$ and dried at $40^{\circ} \mathrm{C}$, mounted in epoxy, polished and carbon-coated for EPMA. Backscatter images of glass shards were done at the electron microprobe in Kiel.

\section{A2 Electron probe microanalyses}

Glass shards from the tephra layers were analyzed for their major and minor element composition by electron microprobe to gain information about the provenance and enable a robust correlation to existing databases of possible source volcanoes. Analyses were performed using two different electron microprobes, one at the University of Alberta, Edmonton, and a second at GEOMAR, Kiel. These two laboratories host databases for volcanic ash layers from different regions (North America and Kamchatka, respectively), which are relevant to the correlation of the El'gygytgyn tephra layers. The INTAV (INQUA international focus group on tephrochronology) intercomparison of tephrochronology laboratories confirmed the high quality of the microprobe results from both instruments (Kuehn et al., 2011), with both instruments producing data sets that are identical within statistical deviations. In this way interlaboratory calibration issues could be excluded.

\section{A2.1 EPMA - University of Alberta, Canada}

At the University of Alberta, the major-element geochemical composition of single glass shards was analyzed with a JEOL 8900 superprobe. Analytical conditions were a $15 \mathrm{kV}$ accelerating voltage, $6 \mathrm{nA}$ beam current, and $10 \mu \mathrm{m}$ beam diameter, with a $20 \mathrm{~s}$ peak and $10 \mathrm{~s}$ background counting time on all elements. $\mathrm{Na}, \mathrm{Si}$ and $\mathrm{Al}$ were analyzed first to minimize the effects of Na-loss. Standards used for calibration are Lipari rhyolitic obsidian (UA 5831: $\mathrm{Si}, \mathrm{Al}, \mathrm{Na}, \mathrm{K}$ ) and minerals (tugtupite: $\mathrm{Cl}$; diopside: $\mathrm{Ca}$; willemite: $\mathrm{Mn}$; pyrope: $\mathrm{Fe}, \mathrm{Mg}$; ilmenite: $\mathrm{Ti})$. Matrix effects are corrected for using the ZAF correction factor. Internal glass standards ID 3506 (a Lipari obsidian) and Old Crow tephra were analyzed at the beginning, after every four samples (i.e., $\sim 100$ shards), and at the end of each analytical session to monitor quality of the calibration (e.g., Kuehn et al., 2011). Routine internal standard analyses also allow for the comparison of data collected over the course of days to years by providing a means to correct for any small offsets that may be present due to variations in probe conditions over time. A minimum of 25 shards per sample were analyzed to capture the compositional range, and all totals under $90 \%$ were discarded. Data are normalized to $100 \%$ on a volatile-free basis and are presented as weight percent (wt.\%) in Supplement Table S1. All El'gygytgyn tephra layers have been compared to the University of Alberta Alaskan tephra database, with similarity coefficients being calculated for the most similar known Alaskan tephras, and these are presented in Supplement Table S2.

\section{A2.2 EPMA - GEOMAR, Kiel, Germany}

At GEOMAR the chemical composition of single glass shards - major elements, $\mathrm{S}, \mathrm{Cl}$ and $\mathrm{F}$ - was analyzed with a JEOL JXA 8200 electron microprobe equipped with five wavelength dispersive spectrometers including three highsensitivity ones (2 PETH and TAPH). Analytical conditions were $15 \mathrm{kV}$ accelerating voltage; $6 \mathrm{nA}$ beam current and $10 / 10 \mathrm{~s}$ (peak/background) counting time for $\mathrm{Na} ; 20 / 10 \mathrm{~s}$ for $\mathrm{Si}, \mathrm{Al}, \mathrm{Fe}, \mathrm{Mg}$ and $\mathrm{Ca} ; 30 / 15 \mathrm{~s}$ for $\mathrm{K}, \mathrm{Ti}, \mathrm{Cl}$ and $\mathrm{S}$; and 40/20 s for $\mathrm{Mn}$ and F. Analyses were performed with a $5 \mu \mathrm{m}$ electron beam. Standards used for calibration were natural reference material from the Smithsonian collection (rhyolitic glass USNM72854 VG-568 for $\mathrm{Si}, \mathrm{Al}, \mathrm{Na}$, and K; basaltic glass USNM 113498/1 VG-A99 for P, Fe, Mg, Ti and Ca; and scapolite USNM R6600-1 for S and Cl) (Jarosewich et al., 1980). Sodium was analyzed first during all sessions; sodium loss was not observed. The reference materials and internal standard glasses (KN18, Lipari obsidian) were measured in triplicate at the beginning, after every 60 analyses and at the end of each analytical session. Initial data reduction was done using CITZAF correction (Armstrong, 1995) integrated in JEOL software. Correction for instrumental drift (if any) was done based on deviation of the data for reference samples from their recommended values. The corrections for instrumental drift applied were minor $(<5 \%$ relative to all elements) but allowed the best possible accuracy and reproducibility over long time spans. Only totals above $93 \%$ were accepted. Data were screened to avoid analyses contaminated by micro crystals. To cover the whole range of geochemical variations, at least 20 glass shards in every sample were analyzed. All analytical data presented in Supplement Table S3 are given in wt.\% oxides and are normalized to $100 \%$ totals. 


\section{A3 Laser ablation ICP-MS analyses}

Laser ablation (LA) ICP-MS analyses were performed on a range of individual glass shards for their trace element and $\mathrm{Pb}$ isotope composition in the Department of Geography and Earth Sciences, Aberystwyth University. All analyses were performed using a Coherent GeoLas ArF $193 \mathrm{~nm}$ excimer laser ablation system coupled to a Thermo Finnegan Element 2 sector field ICP-MS. The Aberystwyth laboratory provides established analytical methods for determining the chemical composition of fine-grained pumiceous glass shards with a median size of less than $40 \mu \mathrm{m}$, and allows for the analysis of a pure glass phase at a spatial resolution of $10-20 \mu \mathrm{m}$. In total, 226 single shards were analyzed for their glass trace element concentrations and 190 for their $\mathrm{Pb}$ isotopes. The database for rhyolitic tephras from Alaska/Yukon was largely developed with analyses on this instrument (see for example Preece et al., 2011a).

\section{A3.1 Trace element analysis}

Trace element data were collected for individual shards using 20 and $14 \mu \mathrm{m}$ diameter ablation craters at a laser energy of $10 \mathrm{~J} \mathrm{~cm}^{-2}$ and a repetition rate of $5 \mathrm{~Hz}$ over a $24 \mathrm{~s}$ acquisition. Crater size was varied because of the size of individual glass shards to be analyzed. The minor ${ }^{29} \mathrm{Si}$ isotope was used as the internal standard, and the average concentration of $\mathrm{SiO}_{2}$ for each sample (determined by EPMA) was used to calibrate each analysis, after normalization to an anhydrous basis. The NIST 612 reference glass was used for calibration, with concentrations given in Pearce et al. (1997), and a fractionation factor was applied to the data to account for analytical bias introduced related to the different matrices of the reference standard and the sample (see Pearce et al., 2011). Further details of the setup procedures and discussion of the precisions and accuracies, etc., can be found in Pearce et al. (1996, 1999, 2002, 2004a, 2007, 2011), and ICP-MS and laser operating conditions are summarized in Supplement Table S4. The MPI-DING reference glass ATHO-G (Jochum et al., 2006; Jochum and Stoll, 2008) was analyzed as an unknown under the same operating conditions at the same time, and these analyses are given in Supplement Table S5. Analytical precision is typically within $\pm 5-10 \%$ (depending on concentration and crater diameter), and accuracy is typically around $\pm 5 \%$, when compared with the published GeoReM concentrations for ATHO-G. All individual shard trace element data are presented in Supplement Table S6.

\section{A3.2 Lead isotopes}

$\mathrm{Pb}$ isotope compositions were determined by LA-ICP-MS from individual glass shards for all seven samples at Aberystwyth University. For the $\mathrm{Pb}$ isotope analysis the Thermo Finnegan Element 2 sector field ICP-MS was operated in low resolution mode, and $\mathrm{He}$ was used as the sample gas $\left(0.825 \mathrm{~L} \mathrm{~min}^{-1}\right)$ made up with $\operatorname{Ar}\left(\sim 0.7 \mathrm{~L} \mathrm{~min}^{-1}\right)$. The instrument was optimized to give the greatest sensitivity for ${ }^{208} \mathrm{~Pb}$ from the NIST 612 reference glass. Instrument operating conditions are given in Supplement Table S4. Where possible, analyses were performed using a $30 \mu \mathrm{m}$ diameter laser beam which ablated to a depth of about $20 \mu \mathrm{m}$, although for some samples a $20 \mu \mathrm{m}$ diameter beam had to be used to avoid ablation of mounting resin.

Calibration was achieved from 10 repeat analyses of NIST 612 at the start and end of each set of analyses using the $\mathrm{Pb}$ isotopic ratios from GeoReM (see Jochum et al., 2005; Jochum and Stoll, 2008). Gas blanks (5 repeats) were measured before and after each of the standard analyses, and also between samples. Twenty individual glass shards were analyzed in each unknown, and only two unknowns were analyzed between the NIST reference materials in each set of analyses. This process ensured that reference materials (for calibration and to monitor any instrumental drift) were analyzed at intervals of typically around $1.5 \mathrm{~h}$. Spectra obtained from the NIST 612 glass ( $30 \mu \mathrm{m}$ ablation craters) gave about $270000 \mathrm{cps}$ for ${ }^{208} \mathrm{~Pb}(38.57 \mathrm{ppm} \mathrm{Pb})$, and from the unknown glass shards (with an average of $\sim 12 \mathrm{ppm} \mathrm{Pb}$ ) count rates were lower, averaging $\sim 29000 \mathrm{cps}$, a result of poorer ablation characteristics of natural glasses and the need to use a $20 \mu \mathrm{m}$ diameter crater for many analyses. For each analysis the masses 201, 204, 206, 207, and 208 were measured sequentially and averaged over 100 scans. ${ }^{204} \mathrm{~Pb}$ suffers interference from ${ }^{204} \mathrm{Hg}$, and thus ${ }^{201} \mathrm{Hg}$ was measured to allow a correction for this. Mass bias in the ICP-MS was calculated from the ${ }^{206} \mathrm{~Pb} /{ }^{208} \mathrm{~Pb}$ isotope ratio of the NIST glass after blank subtraction ( $<100 \mathrm{cps}$ on $208 \mathrm{~Pb}$ ), and using this, and the relative isotope abundances of $\mathrm{Hg}$ (Rosman and Taylor, 1998), the calculated contribution of ${ }^{204} \mathrm{Hg}$ (based on the ${ }^{201} \mathrm{Hg}$ intensity) was subtracted from the intensity of the mass 204 peak to leave only ${ }^{204} \mathrm{~Pb}$. Mercury is present as a trace contaminant in the Ar used in ICP-MS, as well as being present in the NIST standard and in natural volcanic glasses; thus any attempt to measure ${ }^{204} \mathrm{~Pb}$ in glasses must compensate for this $\mathrm{Hg}$ interference to the ${ }^{204} \mathrm{~Pb}$ signal. Once the correction for ${ }^{204} \mathrm{Hg}$ had been applied, calibration was achieved using the $\mathrm{Pb}$ isotope ratios given by Jochum et al. (2005), and included correction for any instrument drift during each run. Further considerations of this technique are given in Westgate et al. (2011a). Supplement Table S7 shows the determined $\mathrm{Pb}$ isotope ratios for two USGS glass reference materials, TB-1G and BCR-2G, with the $\mathrm{Pb}$ isotope composition taken from GeoReM (see Jochum and Stoll, 2008). The $\mathrm{Pb}$ isotope ratios determined by LA-ICP-MS analyses are typically within $\pm 0.3 \%$ of the reference isotope ratios, and analytical precision for ratios between ${ }^{206} \mathrm{~Pb},{ }^{207} \mathrm{~Pb}$ and ${ }^{208} \mathrm{~Pb}$ is generally better than $\pm 1 \%$. Ratios to ${ }^{204} \mathrm{~Pb}$ however show worse precision, at about $\pm 1.5 \%$ for TB- $1 \mathrm{G}$ and about $\pm 4.5 \%$ for BCR-2G, despite good accuracy, and this reflects the noise on the Hg signal, which makes a significant contribution to the ${ }^{204} \mathrm{~Pb}$ signal, particularly at low concentrations 
and count rates. In the case of BCR-2G, the ${ }^{204} \mathrm{Hg}$ correction accounts for almost $70 \%$ of the signal at mass 204 , leaving only a few hundred ${ }^{204} \mathrm{~Pb}$ counts. Considering these issues, the size of the ablation craters, and the speed with which analyses can be performed, these data are useful and appropriate for reconnaissance studies of $\mathrm{Pb}$ isotope ratios in tephra deposits (see Westgate et al., 2011a). 


\section{References}

Akinin, V. V. and Miller, E. L.: Evolution of Calc-Alkaline Magmas of the Okhotsk-Chukotka Volcanic Belt, Petrology, 19, 237-277, 2012.

Anderson, P. M., Lozhkin, A. V., and Belaya, B. V.: Younger Dryas in western Beringia (northeastern Siberia), in: Environmental Changes in Beringia During the Quaternary, edited by: Simakov, K. V., North East Interdisciplinary Research Institute, Far East Branch, Russian Academy of Sciences, Magadan, 28-44, 1998 (in Russian).

Armstrong, J. T.: CITZAF - a package of corrections for the quantitative electron microbeam X-ray analysis of thick polished materials, thin films and particulates, Microbeam Anal., 4, 177-200, 1995.

Bazanova, L. I. and Pevzner, M. M.: Khangar: One more active volcano in Kamchatka, Trans-actions (Doklady) of the Russian Academy of Sciences, Earth Sci., 377A, 307-310, 2001.

Belousov, A. B., Belousova, M. G., Grushin, S. Y., and Krestov, P. B.: Historic eruptions of the Chikurachki volcano (Paramushir, Kurile Islands), Volcanol. Seismol., 3, 15-34, 2003 (in Russian with English abstract).

Bindeman, I. N., Leonov, V. L., Izbekov, P. E., Ponomareva, V. V., Watts, K. E., Shipley, N. K., Perepelov, A. B., Bazanova, L. I., Jicha, B. R., Singer, B. S., Schmitt, A. K., Portnyagin, M. V., and Chen, C. H.: Large-volume silicic volcanism in Kamchatka: Ar-Ar, U-Pb ages and geochemical characteristics of major pre-Holocene caldera-forming eruptions, J. Volcanol. Geotherm. Res., 189, 57-80, 2010.

Borchardt, G. A., Aruscavage, P. J., and Millard Jr., H. T.: Correlation of the Bishop Ash, a Pleistocene marker bed, using instrumental neutron activation analysis, J. Sediment. Res., 42, 301306, 1972.

Braitseva, O. A., Litasova, S. N., and Ponomarenko, A. K.: Application of tephrochronological method for dating of the key archaeological site in Eastern Kamchatka, Volcanol. Seismol., 5, 507-514, 1987.

Braitseva, O. A., Melekestsev, I. V., Ponomareva, V. V., and Sulerzhitsky, L. D.: The ages of calderas, large explosive craters and active volcanoes in the Kuril-Kamchatka region Russia, Bull. Volcanol., 57, 383-402, 1995.

Braitseva, O. A., Ponomareva, V. V., Sulerzhitsky, L. D., Melekestsev, I. V., and Bailey, J. C.: Holocene key-marker tephra layers in Kamchatka, Russia, Quaternary Res., 47, 125-139, 1997.

Braitseva, O. A., Bazanova, L. I., Melekestsev, I. V., and Sulerzhitsky, L. D.: Largest Holocene eruptions of Avachinsky volcano, Kamchatka, Volcanol. Seismol., 20, 1-27, 1998.

Brigham-Grette, J., Melles, M., Minyuk, P., and Scientific Party: Overview and significance of a $250 \mathrm{ka}$ paleoclimate record from El'gygytgyn Crater Lake, NE Russia, J. Paleolimnol., 37, 1-16, 2007.

Cao, L. Q., Arculus, R. J., and McKelvey, B. C.: Geochemistry and petrology of volcanic ashes recovered from sites 881 through 884: a temporal record of Kamchatka and Kurile volcanism, edited by: Rea, D. K., Scholl, D. W., and Allan, J. F., Proceedings of the Ocean Drilling Program, Scientific Results, 145, 345-381, 1995.

Davies, S. M., Wastegård, S., and Wohlfarth, B.: Extending the limits of the Borrobol Tephra to Scandinavia and detection of new early Holocene tephras, Quaternary Res., 59, 345-352, 2003.
Davies, S. M., Abbott, P. M., Pearce, N. J. G., Wastegård, S., and Blockley S. P. E.: Integrating the INTIMATE records using tephrochronology: rising to the challenge, Quaternary Sci. Rev., 36, 11-27, doi:10.1016/j.quascirev.2011.04.005, 2012.

Demuro, M., Roberts, R. G., Froese, D. G., Arnold, L. J., Brock, F., and Bronk Ramsey, C.: Optically stimulated luminescence dating of single and multiple grains of quartz from perennially frozen loess in western Yukon Territory, Canada: comparison with radiocarbon chronologies for the late Pleistocene Dawson tephra, Quat. Geochronol., 3, 346-364, 2008.

Derkachev, A. N., Nikolaeva, N. A., and Gorbarenko, S. A.: The peculiarities of supply and distribution of clastogenic material in the Sea of Okhotsk during late Quaternary, Russ. J. Pac. Geology, 23, 37-52, 2004.

Derkachev, A. N., Portnyagin, M. V., Ponomareva, V. V., Gorbarenko, S., Malakhov, M., Nürnberg, D., Riethdorf, E. J. R., Tiedemann, R., and van den Bogaard, C.: Marker tephra layers in the Holocene-Pleistocene deposits of the Bering Sea and the north-western Pacific Ocean, in: KALMAR - Second Bilateral Workshop on Russian-German Cooperation on KurileKamchatka and Aleutean Marginal Sea-Island Arc Systems, 16 May 2005-20 May 2011, Trier, 2011.

Derkachev, A. N., Nikolaeva, N. A., Gorbarenko, S. A, Harada, N., Sakamoto, T., Iijima, K. Sakhno, V. G., Hua Hua, L. V., and Wang, K.: Characteristics and ages of tephra layers in the central Okhotsk Sea over the last 350 kyr, Deep-Sea Res., Part II, 61-64, 179-192, 2012.

Dörfler, W., Feeser, I., van den Bogaard, C., Dreibrodt, S., Erlenkeuser, H., Kleinmann, A., and Merkt, J.: A high-quality annually laminated sequence from Lake Belau, Northern Germany: Revised chronology and its implications for palynological and tephrochronological studies, The Holocene, 22, 1413-1426, doi:10.1177/0959683612449756, 2012.

Dugmore, A.: Icelandic volcanic ash in Scotland, Scottish Geographical Magazine, 105, 168-172, 1989.

Dullo, C., Baranov, B., and van den Bogaard, C.: RV Sonne Fahrtbericht, Cruise Report SO201-2: KALMAR (Kurile-Kamchatka and Aleutian Marginal Sea-Island Systems): Geodynamic and Climate Interaction in Space and Time, IFM-GEOMAR Report 35, 1-233, 2009.

Froese, D. G., Westgate, J. A., Sanborn, P. T., Reyes, A. V., and Pearce, N. J. G.: The Klondike goldfields and Pleistocene environments of Beringia, GSA Today, 19, 4-10, doi:10.1130/GSATG54A.1, 2009.

George, R. M. M., Turner, S. P., Hawkesworth, C. J., Bacon, C. R., Nye, C., Stelling, P., and Dreher, S.: Chemical versus temporal controls on the evolution of tholeiitic and calc-alkaline magmas at two volcanoes in the Alaska-Aleutian arc, J. Petrology, 45, 203-219, 2004.

Giaccio, B., Nomade, S., Wulf, S., Isaia, R., Sottili, G., Cavuoto, G., Galli, P., Sposato, A., Sulpizio, R., and Zanchetta, G.: The late MIS 5 Mediterranean tephra markers: a reappraisal from peninsular Italy terrestrial records, Quaternary Sci. Rev., 56, 31-45, doi:10.1016/j.quascirev.2012.09.009, 2012.

Gill, J. B.: Orogenic andesites and plate tectonics, Springer-Verlag, Berlin-Heidelberg, 1981. 
Gorbarenko, S. A., Chekhovskaya, M. P., and Southon, J. R.: Detailed environmental changes of the Sea of Okhotsk Central part during the last glaciation-Holocene, Oceanology, 38, 277-280, 1998.

Gorbarenko, S. A., Derkachev, A. N, Astakhov, A. S., Southon, J. R., Nuernberg, D., and Shapovalov-Chuprynin, V. V.: Lithostratigraphy and tephrochronology of the upper Quaternary sediments of the Sea of Okhotsk, Tikhookeanskaya Geologiya, 19, 58-72, 2000 (in Russian).

Gorbarenko, S. A., Khusid, T. A., Basov, I. A., Oba, T., Southon, J. R., and Koizumi, I.: Glacial Holocene environment of the southeastern Okhotsk Sea: evidence from geochemical and palaeontological data, Palaeo, 3, 177, 237-263, 2002a.

Gorbarenko, S. A., Nuernberg, D., Derkachev, A. N., Astachov, A. S., Southon, J. R., and Kaiser, A,: Magnetostratigraphy and tephrochronology of the Upper Quaternary sediments in the Okhotsk Sea: implication of terrigenous, volcanogenic and biogenic matter supply, Mar. Geol., 183, 107-129, 2002 b.

Gorshkov, G. S.: Structure of the Kurile Arc, in Volcanism and the Upper Mantle, Springer US, 1-6, 1970.

Grönvold, K., Oskarsson, N., Johnsen, S. J., Clausen, H. B., Hammer, C. U., Bond, G., and Bard, E.: Ash layers from Iceland in the Greenland GRIP ice core correlated with oceanic and land sediments, Earth Planet. Sci. Lett., 135, 149-155, 1995.

Gurov, E. P., Valter, A. A., Gurova, E. P., and Serebrennikov, A. I.: Explosion meteorite crater El'gygytgyn in Chukotka. Akademiia Nauk SSSR, Doklady, 240, 1407-1410, 1978.

Gurov, E. P., Koeberl, C., and Yamnichenko, A.: El'gygytgyn impact crater, Russia: Structure, tectonics, and morphology, Meteorit. Planet. Sci., 42, 307-319, 2007.

Gusev, A. A., Ponomareva, V. V., Braitseva, O. A., Melekestsev, I. V., and Sulerzhitsky, L. D.: Great explosive eruptions on Kamchatka during the last 10,000 years: self-similar irregularity of the output of volcanic products, J. Geophys. Res., 108/B2, 2126, doi:10.1029/2001JB000312, 2003.

Hall, C. M. and Farrell, J. W.: Laser ${ }^{40} \mathrm{Ar} /{ }^{39} \mathrm{Ar}$ ages of tephra from Indian Ocean deep-sea sediments: Tie points for the astronomical and geomagnetic polarity time scales, Earth Planet. Sc. Lett., 133, 327-338, 1995 .

Haltia, E. M. and Nowaczyk, N. R.: Magnetostratigraphy of sediments from Lake El'gygytgyn ICDP Site 5011-1: paleomagnetic age constraints for the longest paleoclimate record from the continental Arctic, Clim. Past Discuss., 9, 5077-5122, doi:10.5194/cpd-9-5077-2013, 2013.

Hasegawa, T., Nakagawa, M., Yoshimoto, M., Ishizuka, Y., Hirose, W., Seki, S., Ponomareva, V., and Alexander, R.: Tephrostratigraphy and petrological study of Chikurachki and Fuss volcanoes, western Paramushir Island, northern Kurile Islands: Evaluation of Holocene eruptive activity and temporal change of magma system, Quaternary Int., 1-20, 278-297, doi:10.1016/j.quaint.2011.06.047, 2012.

Hopkins, D. M.: The Bering Land Bridge, Stanford University Press, Stanford, CA, 1967.

Hughes, G. R. and Mahood, G. A.: Tectonic controls on the nature of large silicic calderas in volcanic arcs, Geology, 36, 627-630, doi:10.1130/G24796A.1, 2008.

Hultén, E.: Outline of the History of Arctic and Boreal Biota During the Quarternary Period, Lehre J Cramer, New York, 1937.
Jarosewich, E. J., Nelen, J. A., and Norberg, J. A.: Reference samples for electron microprobe analysis, Geostandards Newsletter, 4, 43-47, 1980.

Jensen, B., Froese, D., Preece, S., Westgate, J., and Stachel, T.: An extensive middle to late Pleistocene tephrochronologic record from east-central Alaska, Quaternary Sci. Rev., 27, 411-427, 2008.

Jensen, B. J. L., Preece, S. J., Lamothe, M., Pearce, N. J. G., Froese, D. G., Westgate, J. A., Schaefer, J., and Begét, J.: The variegated (VT) tephra: A new regional marker for middle to late marine isotope stage 5 across Yukon and Alaska, Quaternary Int., 246, 312-323, doi:10.1016/j.quaint.2011.06.028, 2011.

Jensen, B. J. L., Pyne-O’Donnell, S., Plunkett, G., Froese, D. G., Hughes, P., Pilcher, J. R., and Hall, V. A.: Intercontinental distribution of an Alaskan volcanic ash, Abstract V43B-2832 of the AGU Fall Meeting, San Francisco, 3-7 December, 2012.

Jensen, B. J. L., Reyes, A. V., Froese, D. G., and Stone, D. B.: The Palisades is a key reference site for the middle Pleistocene of eastern Beringia: new evidence from paleomagnetics and regional tephrostratigraphy, Quaternary Sci. Rev., 63, 91-108, doi:10.1016/j.quascirev.2012.11.035, 2013.

Jicha, B. R., Singer, B. S., Brophy, J. G., Fournelle, J. H., Johnson, C. M., Beard, B. L., Lapen, T. J., and Mahlen, N. J.: Variable impact of the subducted slab on Aleutian island arc magma sources: Evidence from $\mathrm{Sr}, \mathrm{Nd}, \mathrm{Pb}$, and $\mathrm{Hf}$ Isotopes and trace element abundances, J. Petrol., 45, 1845-1875, 2004.

Jicha, B. R., Scholl, D. W., Singer, B. S., Yogodzinski, G. M., and Kay, S. M.: Revised age of Aleutian Island Arc formation implies high rate of magma production, Geology, 34, 661-664, doi:10.1130/G22433.1, 2006.

Jochum, K.-P. and Stoll, B.: Reference materials for elemental and isotopic analysis by LA-(MC)-ICP-MS: Successes and outstanding needs, in: Laser Ablation-ICP-MS in the Earth Sciences, edited by: Sylvester, P., Current practices and outstanding issues., Mineralogical Association of Canada (MAC) Short Course Series, Vancouver, 147-168, 2008.

Jochum, K.-P., Nohl, U., Herwig, K., Lammel, E., Stoll, B., and Hofmann, A. W.: GeoReM: A New Geochemical Database for Reference Materials and Isotopic Standards, Geostand. Geoanal. Res., 29, 333-338, 2005.

Jochum, K.-P., Stoll, B., Herwig, K., Willbold, M., Hofmann, A. W., Amini, M., Aarburg, S. E., Abouchami, W., Hellebrand, E., Mocek, B., Raczek, I., Stracke, A., Alard, O., Bouman, C., Becker, S., Ducking, M., Bratz, H., Klemd, R., de Bruin, D., Canil, D., Cornell, D., de Hoog, C. J., Dalpe, C., Danyushevsky, L., Eisenhauer, A., Gao, Y. J., Snow, J. E., Goschopf, N., Gunther, D., Latkoczy, C., Guillong, M., Hauri, E. H., Hofer, H. E., Lahaye, Y., Horz, K., Jacob, D. E., Kassemann, S. A., Kent, A. J. R., Ludwig, T., Zack, T., Mason, P. R. D., Meixner, A., Rosner, M., Misawa, K. J., Nash, B. P., Pfander, J., Premo, W. R., Sun, W. D. D., Tiepolo, M., Vannucci, R., Vennemann, T., Wayne, D., and Woodhead, J. D.: MPI-DING reference glasses for in situ microanalysis: New reference values for element concentrations and isotope ratios, Geochem., Geophys., Geosy., 7, Q02008, doi:10.01029/02005GC001060, 2006.

Juschus, O., Preusser, F., Melles, M., and Radtke, U.: Applying SAR-IRSL methodology for dating fine-grain sediments from Lake El'gygytgyn, northeastern Siberia, Quat. Geochronol., 2, 187-194, 2007. 
Juschus, O., Melles, M., Gebhardt, A. C., and Niessen, F.: Late Quaternary mass move- ment events in Lake El'gygytgyn, north-eastern Siberia, Sedimentology, 56, 21552174, doi:10.1111/j.1365-3091.2009.01074.x, 2009.

Gill, J. B.: Orogenic andesites and plate tectonics, Springer-Verlag, Berlin-Heidelberg, 1981.

Kaufman, D. S., Jensen, B. J. L., Reyes, A. V., Schiff, C. J., Froese, D. G., and Pearce N. J. G.: Late Quaternary tephrostratigraphy, Ahklun Mountains, SW Alaska, J. Quaternay Sci., 27, 344-359, doi:10.1002/jqs.1552, 2012.

Kepezhinskas, P., McDermott, F., Defant, M. J., Hochstaedter, A., Drummond, M. S., Hawkesworth, C. J., Koloskov, A., Maury, R. C., and Bellon, H.: Trace element and $\mathrm{Sr}-\mathrm{Nd}-\mathrm{Pb}$ isotopic constraints on a three-component model of Kamchatka Arc petrogenesis, Geochim. Cosmochim. Ac., 61, 577-600, 1997.

Kir'yanov, V. Yu., Egorova, I. A., and Litasova, S. N.: Volcanic ash on Bering Island (Commander Islands) and Kamchatkan Holocene eruptions, Volcanol. Seismol., 8, 850-868, 1990.

Kuehn, S. C., Froese, D. G., Shane, P. A. R., and Participants, I. I.: The INTAV intercomparison of electron-beam microanalysis of glass by tephrochronology laboratories: Results and recommendations, Quaternary Int., 246, 19-47, doi:10.1016/j.quaint.2011.08.022, 2011.

Kyle, P. R., Ponomareva, V. V., and Rourke-Schluep, R.: Geochemical characterization of marker tephra layers from major Holocene eruptions in Kamchatka, Russia, Int. Geol. Rev., 53, 1059-1097, 2011.

Lane, C. S., Chorn, B. T., and Johnson, T. C.: Ash from the Toba supereruption in Lake Malawi shows no volcanic winter in East Africa at $75 \mathrm{ka}$, Proc. Natl. Acad. Sci., 110, 8025-8029, doi:10.1073/pnas.1301474110 (Supplement), 2013.

Laverov, N. P., Kovalenko, V. I., Yarmolyuk, V. V., Bogatikov, O. A., Akinin, V. V., Gurbanov, A. G., Evdokimov, A. N., Kudryashova, E. A., Pevzner, M. M., Ponomareva, V. V., and Sakhno, V. V.: Recent volcanism of northern Eurasia: Regionalization and formation settings, Doklady Earth Sci., 410, 1048-1052, 2006.

Layer, P.: Argon ${ }^{40} / \operatorname{argon}^{39}$ age of the Elgygytgyn impact event, Chukotka, Russia, Meteor. Planet. Sci., 35, 591-599, 2000.

Le Bas, M., Le Maitre, R., Streckeisen, A., and Zanettin, B.: A chemical classification of volcanic rocks based on the total alkali-silica diagram, J. Petrol., 27, 745-750, 1986.

Melekestsev, I. V., Volynets, O. N., and Antonov, A. Y.: Nemo III Caldera (Onekotan I., the Northern Kuriles): Structure, ${ }^{14} \mathrm{C}$ age, dynamics of the caldera-forming eruption, evolution of juvenile products, Volcan. Seism., 19, 41-64, 1997.

Melles, M., Brigham-Grette, J., Minyuk, P., Koeberl, C., Andreev, A., Cook, T., Fedorov, G., Gebhardt, C., Haltia-Hovi, E., Kukkonen, M., Nowaczyk, N., Schwamborn G., Wennrich, V., and the El'gygytgyn Scientific Party: The El'gygytgyn Scientific Drilling Project - conquering Arctic challenges through continental drilling, Sci. Drilling, 11, 29-40, 2011.

Melles, M., Brigham-Grette, J., Minyuk, P. S., Nowaczyk, N. R., Wennrich, V., DeConto, R. M., Anderson, P. M., Andreev, A. A., Coletti, A., Cook, T. L., Haltia-Hovi, E., Kukkonen, M., Lozhkin, A. V., Rosén, P., Tarasov, P., Vogel, H., and Wagner, B.: 2.8 Million Years of Arctic Climate Change from Lake El'gygytgyn, NE Russia, Science, 337, 315-320, doi:10.1126/science.1222135, 2012.
Minyuk, P. S. and Ivanov, Y. Y.: The Brunhes-Matuyama boundary in Western Beringia: a review, Quaternary Sci. Rev., 30, 2054 2068, doi:10.1016/j.quascirev.2010.06.008, 2011.

Myers, J. D. and Marsh, B. D.: Aleutian lead isotopic data: additional evidence for the evolution of lithospheric plumbing systems, Geochem. Cosmochim. Acta, 51, 1833-1842, 1987.

Nakagawa, M., Ishizuka, Y., Kudo, T., Yoshimoto, M., Hirose, W., Ishizaki, Y., Gouchi, N., Katsui, Y., Solovyow, A. W., Steinberg, G. S., and Abdurakhmanov, A. I.: Tyatya volcano, southwestern Kuril arc: recent eruptive activity inferred from widespread tephra, Island Arc., 11, 236-254, 2002.

Nürnberg, D. and Tiedemann, R.: Environmental change in the Sea of Okhotsk during the last 1.1 million years, Paleoceanography, 19, A4011, doi:10.1029/2004PA001023, 2004.

Nowaczyk, N. R., Haltia, E. M., Ulbricht, D., Wennrich, V., Sauerbrey, M. A., Rosén, P., Vogel, H., Francke, A., MeyerJacob, C., Andreev, A. A., and Lozhkin, A. V.: Chronology of Lake El'gygytgyn sediments - a combined magnetostratigraphic, palaeoclimatic and orbital tuning study based on multiparameter analyses, Clim. Past, 9, 2413-2432, doi:10.5194/cp-92413-2013, 2013.

Nye, C. J., Queen, K., and McCarthy, A. M.: Volcanoes of Alaska: Alaska Division of Geological and Geophysical Surveys Information Circular IC 0038, 1998.

Ostapenko, V. F., Fedorchenko, V. I., and Shilov, V. N.: Pumices, ignimbrites and rhyolites from the Great Kurile Arc, Bull. Volcanol., 30, 81-92, 1967.

Pearce, J. A. and Parkinson, I. J.: Trace element models for mantle melting: application to volcanic arc petrogenesis, in: Magmatic Processes and Plate Tectonics, edited by: Prichard, H. M., Alabaster, T., Harris, N. B., and Neary, C. R., Geol. Soc. Spec. Publ., 76, 373-403, 1993.

Pearce, N. J. G., Westgate, J. A., and Perkins, W. T.: Developments in the analysis of volcanic glass shards by Laser Ablation ICP-MS: quantitative and single internal standard-multi-element methods, Quaternary Int., 34-36, 213-227, 1996.

Pearce, N. J. G., Perkins, W. T., Westgate, J. A., Gorton, M. P., Jackson, S.E., Neal, C. R., and Chenery, S. P.: A compilation of new and published major and trace element data for NIST SRM 610 and NIST SRM 612 glass reference materials, Geostand. Newslett., 115-144, 1997.

Pearce, N. J. G., Westgate, J. A., Perkins, W. T., Eastwood, W. J., and Shane, P. A. R.: The application of laser ablation ICP-MS to the analysis of volcanic glass shards from tephra deposits: bulk glass and single shard analysis, Global Planet. Change, 21, 151171, 1999.

Pearce, N. J. G., Eastwood, W. J., Westgate, J. A., and Perkins, W. T.: The composition of juvenile volcanic glass from the c. 3,600 B.P. Minoan eruption of Santorini (Thera), J. Geol. Soc., 159, 545-556, 2002.

Pearce, N. J. G., Westgate, J. A., Perkins, W. T., and Preece, S. J.: The application of ICP-MS methods to tephrochronological problems, Appl. Geochem., 19, 289-322, 2004a.

Pearce, N. J. G., Westgate, J. A., Preece, S. J., Eastwood, W. J., and Perkins, W. T.: Identification of Aniakchak (Alaska) tephra in Greenland ice core challenges the 1645 BC date for Minoan eruption of Santorini, Geochem. Geophys. Geosyst., 5, Q03005, doi:10.1029/2003GC000672, 2004b. 
Pearce, N. J. G., Denton, J. S., Perkins, W. T., Westgate, J. A., and Alloway, B. V.: Correlation and characterisation of individual glass shards from tephra deposits using trace element laser ablation ICP-MS analyses: current status and future potential, J. Quaternary Sci., 22, 721-236, 2007.

Pearce, N. J. G., Perkins W. T. Westgate J. A., and Wade S. C.: Trace element analysis by laser ablation ICP-MS: the quest for comprehensive chemical characterisation of single sub-10 $\mu \mathrm{m}$ volcanic glass shards, Quaternary Int., 246, 57-81, 2011.

Pevzner, M. M., Gertsev, D. O., Romanenko, F. A., and Kushcheva, Y. V.: The first data on isotopic age of Anyui volcano (Chukotka), in: Doklady Earth Sciences, 438, 736-738, 2011.

Pilcher, J. R., Hall, V. A., and McCormac, F. G.: An outline tephrochronology for the Holocene of the north of Ireland, J. Quaternary Sci., 11, 485-494, 1996.

Ponomareva, V. V., Kyle, P. R., Melekestev, I. V., Rinkleff, P. G., Dirksen, O. V., Sulerzhitsky, L. D., Zaretskaia, N. E., and Rourke R.: The $7600\left({ }^{14} \mathrm{C}\right)$ year BP Kurile Lake caldera-forming eruption, Kamchatka, Russia: stratigraphy and field relationships, J. Volcanol. Geotherm. Res., 136, 199-222, 2004.

Ponomareva, V. V., Churikova, T. G., Melekestsev, I. V., Braitseva, O. A., Pevzner, M. M., and Sulerzhitsky, L. D.: Late PleistoceneHolocene Volcanism on the Kamchatka Peninsula, Northwest Pacific region, in: Volcanism and subduction: the Kamchatka Region, edited by: Eichelberger, J., Izbekov, P., Ruppert, N., Lees, J., and Gordeev, E., AGU Geophysical Monograph Series, 172, 165-198, 2007.

Ponomareva, V. V., Portnyagin, M. V., Derkachev, A. N., Pendea, I. F., Bourgeois, J., Reimer, P. J., Garbe-Schönberg, D., and Krasheninnikov, S.: Early Holocene $M \sim 6$ explosive eruption from Plosky volcanic massif (Kamchatka) and its tephra as a link between terrestrial and marine paleoenvironmental records, Int. J. Earth Sci., 102/6, 1673-1699, doi:10.1007/s00531-013-08980, 2013a.

Ponomareva, V. V., Portnyagin, M. V., Derkachev, A. N., Juschus, O., Garbe-Schönberg, D., and Nürnberg, D.: Identification of a widespread Kamchatkan tephra: A middle Pleistocene tie-point between Arctic and Pacific paleoclimatic records, Geophys. Res. Lett., 40/14, 3538-3543, doi:10.1002/grl.50645, 2013 b.

Preece, S., Westgate, J., Stemper, B., and Péwé, T.: Tephrochronology of late Cenozoic loess at Fairbanks, central Alaska, Geol. Soc. Am. Bull., 111, 71-90, 1999.

Preece, S. J., Westgate, J. A., Alloway, B. V., and Milner, M. W.: Characterization, identity, distribution, and source of late Cenozoic tephra beds in the Klondike district of the Yukon, Canada, Can. J. Earth Sci., 37, 983-996, 2000.

Preece, S. J., Westgate, J. A., Froese, D. G., Pearce, N. J. G., Perkins, W. T., and Fisher, T.: A catalogue of late Cenozoic tephra beds in the Klondike goldfields and adjacent areas, Yukon Territory, Can. J. Earth Sci., 48, 1386-1418, doi:10.1139/e10110, 2011a.

Preece, S. J., Pearce, N. J. G., Westgate, J. A., Froese, D. G., Jensen, B. J. L., and Perkins, W. T.: Old Crow tephra across eastern Beringia: a single cataclysmic eruption at the close of Marine Isotope Stage 6, Quaternary Sci. Rev., 30, 2069-2090, doi:10.1016/j.quascirev.2010.04.020, 2011 b.

Prueher, L. M. and Rea, D. K.: Tephrochronology of the Kamchatka-Kurile and Aleutian arcs: evidence for volcanic episodicity, J. Volcanol. Geotherm. Res., 106, 67-84, 2001.
Pyne-O’Donnell, S. D. F., Hughes, P. D. M., Froese, D. G., Jensen, B. J. L., Kuehn, S. C., Mallon, G., Amesbury, M.J., Charman, D. J., Daley, T. J., Loader, N. J., Mauquoy, D., Alayne StreetPerrott, A., and Woodman-Ralph, J.: High-precision ultra-distal Holocene tephrochronology in North America, Quaternary Sci. Rev., 52, 6-11, doi:10.1016/j.quascirev.2012.07.024, 2012.

Reyes, A. V., Froese, D. G., and Jensen, B. J. L.: Permafrost response to last interglacial warming: field evidence from nonglaciated Yukon and Alaska, Quaternary Sci. Rev., 29, 32563274, doi:10.1016/j.quascirev.2010.07.013, 2010.

Richter, D. H., Smith, J. G., Lanphere, M. A., Dalrymple, G. B., Reed, B. L., and Shew, N.: Age and progression of volcanism, Wrangell volcanic field, Alaska, Bull. Volcanol., 53, 29-44, 1990.

Rosman, K. J. R. and Taylor, P. D. P.: Isotopic compositions of the elements 1997, J. Phys. Chem. Ref. Data, 27, 1275-1287, 1998.

Sauerbrey, M. A., Juschus, O., Gebhardt, A. C., Wennrich, V., Nowaczyk, N. R., and Melles, M.: Mass movement deposits in the 3.6 Ma sediment record of Lake El'gygytgyn, Far East Russian Arctic, Clim. Past, 9, 1949-1967, doi:10.5194/cp-9-19492013, 2013.

Schirrmeister, L., Froese, D., Tumskoy, V., Grosse, G., and Wetterich, S.: Yedoma: Late Pleistocene ice-rich syngenetic permafrost of Beringia, Encyclopedia Quaternary Sci., 3, 542-552, 2013.

Shane, P. A. R., Black, T. M., Alloway, B. V., and Westgate, J. A.: Early to middle Pleistocene tephrochronology of North Island, New Zealand: Implications for volcanism, tectonism, and paleoenvironments, Geol. Soc. Am. Bull., 108, 915-925. doi:10.1130/0016-7606(1996)108<0915:ETMPTO>2.3.CO;2, 1996.

Sher, A. V.: Problems of the last interglacial in Arctic Siberia, Quaternary Int., 10-12, 215-222, 1991.

Sher, A. V.: Yedoma as a store of paleoenvironmental records in Beringida, in: Beringia Paleoenvironmental Workshop, edited by: Elias, S. and Brigham-Grette, J., September 1997, Abstracts and Program, 92-94, 1997.

Siebert, L. and Simkin, T.: Volcanoes of the World: an Illustrated Catalog of Holocene Volcanoes and their Eruptions. Smithsonian Institution, Global Volcanism Program, Digital Information Series, GVP-3, available at: http://www.volcano.si.edu (last access: July 2013), 2002.

Sun, S. and McDonough, W. F.: Chemical and isotopic systematics of oceanic basalts: implications for mantle compositions and processes, in: Magmatism in the Ocean Basins, edited by: Sanders, A. D. and Norry, M. J., Geological Society Special Publication, 313-345, 1989.

van den Bogaard, C. and Schmincke, H. U.: Linking the North Atlantic to central Europe: a high-resolution Holocene tephrochronological record from northern Germany, J. Quaternary Sci., 17, 3-20, doi:10.1002/jqs.636, 2002.

Wastegård, S.: Late Quaternary tephrochronology of Sweden: a review, Quaternary Int., 130, 49-62, doi:10.1016/j.quaint.2004.04.030, 2002.

Westgate, J., Stemper, B., and Péwé, T.: A 3 My record of PliocenePleistocene loess in interior Alaska, Geology, 18, 858-861, 1990. 
Westgate, J., Preece, S., Froese, D., Walter, R., Sandhu, A., and Schweger, C.: Dating early and middle (Reid) Pleistocene glaciations in central Yukon by tephrochronology, Quaternary Res., 56, 335-348, 2001.

Westgate, J. A., Preece, S. J., Froese, D. G., Telka, A. M., Storer, J. E., Pearce, N. J. G., Enkin, R. J., Jackson, L. E., LeBarge, W., and Perkins, W. T.: Gold Run tephra: a Middle Pleistocene stratigraphic and paleoenviromental marker across west-central Yukon Territory, Canada, Can. J. Earth Sci., 46, 465-478, 2009.
Westgate, J. A., Pearce, N. J. G., Perkins, W. T., Shane, P., and Preece, S. J.: Lead isotope ratios of volcanic glass by laser ablation inductively-coupled plasma mass spectrometry: Application to Miocene tephra beds in Montana, USA and adjacent areas, Quaternary Int., 246, 82-96, 2011a.

Westgate, J. A., Preece, S. J., and Jackson, L. E.: Revision of the tephrostratigraphy of the lower Sixtymile River area, Yukon Territory, Canada, Can. J. Earth Sci., 48, 695-701, 2011 b. 